\title{
NOVÉ ARCHEOLOGICKÉ PRAMENE K OSÍDLENIU KOŠICKÝCH PREDMESTÍ V STREDOVEKU A VČASNOM NOVOVEKU ${ }^{1}$
}

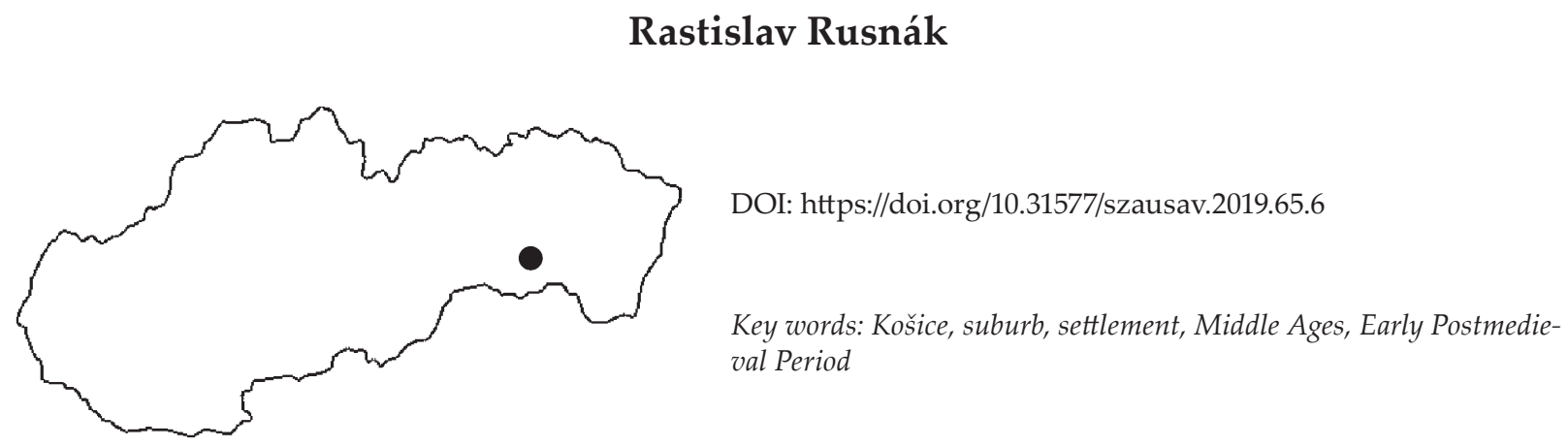

New Archaeological Sources Associated with Settlement of Košice Suburbs in the Middle Ages and Early Postmedieval Period

The paper sums up the results of archaeological research in the wider center of Košice. After several decades it has brought out new archaeological sources of southern suburbs settlement from the Middle Ages and the Early Modern Age. The relics of settlement are rather simple in terms of numbers and expression and so are the findings of material culture. However the added value is the fact that they have enriched a very narrow range of previously known findings from the area of former Košice suburbs and they have provided a good opportunity for their placement in the local historical and spatial context.

\section{ÚVOD}

Doteraz známe archeologické pramene viažuce sa $\mathrm{k}$ stredovekému a včasnonovovekému osídleniu košických predmestí sú počtom vel’mi chudobné. Je to tak aj napriek tomu, že v priestore bývalých južných a západných predmestí prešlo územie v druhej polovici 20. stor. vel'kou urbanistickou zmenou. Relikty sídelných foriem, vychádzajúcich z tradície pôvodných predmestí, takmer úplne nahradila rozsiahla rezidenčná výstavba, doplnená rozmanitou polyfunkčnou zástavbou. Tento proces, tažiskovo prebiehajúci v 70. a 80. rokoch 20. stor., žial', prebehol bez archeologického dohladu. Aj preto sa až do minulého roku evidovali iba dva archeologické nálezy, ktoré časovo i priestorovo súvisia so stredovekým predmestským osídlením. Oba boli zachytené ešte na prelome 50. a 60. rokov 20. stor. V prvom prípade bol odkrytý a zdokumentovaný neskorostredoveký objekt hrnčiarskej pece na Šrobárovej ul. 57 (obr. 1a), ned’aleko bývalej Hnilnej brány, teda v priestore západných predmestí, odkial pochádza 15 celých retort na praženie rumelky (Pástor 1959, obr. 11; 12; Slivka 1978, 233). V druhom prípade z roku 1963 narušila prebiehajúca výstavba na Južnej triede 6, v blízkosti špitála sv. Ducha na bývalom južnom predmestí, stredoveký sídliskový objekt (Lamiová-Schmiedlová 1970, 149). Pokračujúca výstavba v tých miestach zároveň narušila kostrové hroby zo 17.-18. stor. (Lamiová-Schmiedlová/Miroššayová 1991, 41). S vel'kou pravdepodobnostou išlo o zásah do severovýchodného okraja vel'kého mestského cintorína, ktorý sa v danom priestore nachádzal na hranici s južným predmestím (obr. 1b). Zmienił ešte možno výskum z roku 1993, pri ktorom sa na rohu ulíc Štúrovej a Murgašovej našlo 11 hrobov radového cintorína datovaného nálezmi do 17. stor. (Lamiová-Schmiedlová 1995, 87). Menší cintorín, približne v týchto miestach, je zobrazený i na tzv. Pálfyho mape z roku 1742 (OrosoválŽažová 2011, 60). Je situovaný do priestoru medzi domami severozápadného okraja južného predmestia a zemným násypom pred ravelinom sv. Karola mestského opevnenia (obr. 1c).

Označenie určitej sídelnej štruktúry ako predmestie v sebe nesie predpoklad, že v susedstve existuje iná sídelná štruktúra s výsadným postavením a spravidla ohradená hradbami. Predmestie pred hradbami môže byt๋ výsledkom dodatočného osídlenia, ale môže byt๋ i pozostatkom staršieho sídla, ktoré sa

1 Práca vznikla v rámci projektu 1/0727/17 agentúry VEGA. 


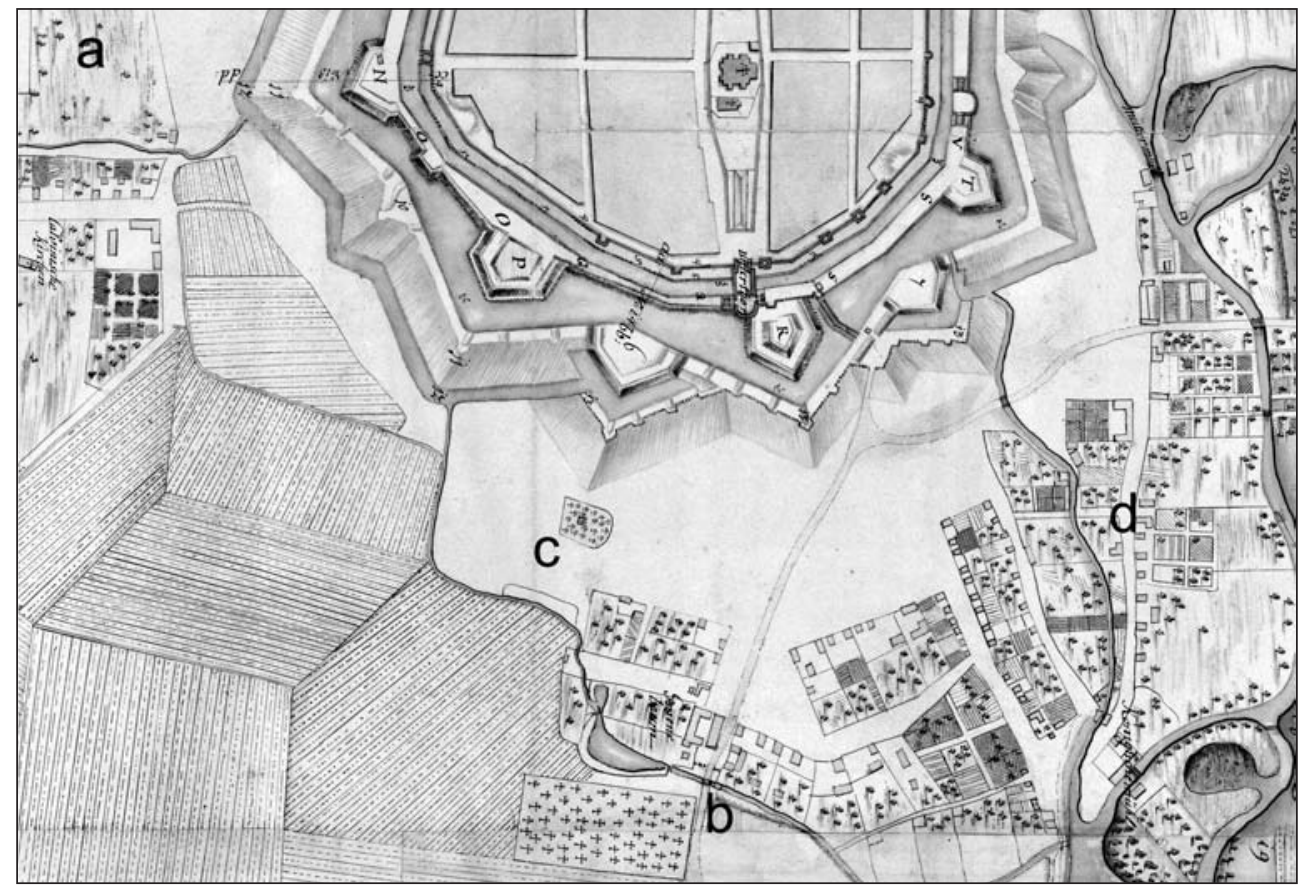

Obr. 1. Výsek z mapy Košíc z roku 1742 (Orosová/Žažová 2011, 60) s vyznačením doterajších i aktuálneho archeologického dokladu predmestského osídlenia. a - približná lokalizácia nálezu hrnčiarskej pece z roku 1959 na Šrobárovej 57; b - približná lokalizácia nálezu stredovekého sídliskového objektu z roku 1963, ned’aleko okraja novovekého mestského cintorína; c - lokalizácia menšieho cintorína, čiastočne zachyteného výskumom z roku 1993; d - približná lokalizácia predmestských nálezov referovaných v príspevku.

z nejakej príčiny nedostalo do novovymedzených hraníc opevneného mesta. Tematike vzniku, vývoja a správy košických predmestí sa v minulosti bližšie venovalo viacero autorov (Duchoň 2000-2001; Halaga 1993; Uličný 2014; Varsik 1948), naposledy obšírne D. Magdoško (2013; 2017). Pri hladaní počiatkov osídlenia na predmestiach Košíc stále čelíme absencii priamych dokladov. Chýbajú archeologické i písomné pramene. Práve južné predmestie je spolu so severným tým, $\mathrm{v}$ ktorého prípade sa $\mathrm{v}$ minulosti uvažovalo v súvislosti s predkolonizačným osídlením. Indícií pre takéto tvrdenie je viacero. Najviac sa do úvahy berie tunajšia prítomnost̉ mestského špitála, $\mathrm{v}$ písomných prameňoch po prvýkrát doloženého $\mathrm{v}$ roku 1283 (Archív mesta Košice 1). Neskorý údaj z levočskej kroniky Gašpara Haina spomína jeho založenie v roku 1216 (Bal/Jenő/Kauffmann 1910-1913, 10), čo viedlo niektorých bádatelov k spájaniu jeho sakrálnej časti s kostolom spomínaným v prvej písomnej zmienke o Košiciach z roku 1230 (Duchoň 2000-2001, 11, 12). K tomu možno prirátat i skutočnost', že špitál sa nachádzal v blízkosti križovania dvoch najdôležitejších krajinských ciest do Košíc (Magdoško 2017, 595). Prvý písomný údaj, priamo zmieňujúci košické predmestia, je až z roku 1347, adresne južné predmestia, známe najmä pod označením Ludmanova ves (villa Ludmani, Ludmansdorf) a Špitálska ulica (platea hospitalis, Spitel gasse) až z roku 1394 (Magdoško 2017, 597-599). Pre kontext tohto príspevku sú dôležité ešte dva údaje. V súvislosti s udalostami z roku 1491, ked' vojská pol’ského princa Jána Albrechta obliehali Košice sa spomína, že predmestia boli vypálené, ovocné stromy vyrúbané a špitál zborený (Wick 1936, 37). Osídlenie sa pravdepodobne čoskoro obnovilo, svedčia o tom daňové registre už od počiatku 16. stor. (Magdoško 2017, 597, 598). V roku 1671 bol priestor južných predmestí vytipovaný plukovníkom Jacobom von Holstom ako najvhodnejší pre umiestnenie plánovanej výstavby pätcípej citadely (Österreichisches Staatsarchiv Wien 1671). Nasledujúce udalosti mali rýchly spád. Už v priebehu leta 1671 bolo z nariadenia cisára Leopolda celé južné predmestie s výnimkou špitála asanované a začalo sa s výstavbou rozsiahlej barokovej pevnosti (Archív mesta Košice 2; Orosová/Žažová 2011, 135). Tento letopočet možno s istotou považovat za hornú hranicu predmestského osídlenia v juhovýchodnej časti mesta. Bol to mílnik, ktorým bola tunajšia stredoveká a včasnonovoveká sídelná tradícia na dlhší čas výrazným spôsobom prerušená. Je známe, že ani citadela nemala dlhé trvanie. S pominutím tureckého nebezpečenstva a potlačením Thökőlyho povstania postupne strácala svoje opodstatnenie, neujali sa ani plány jej prestavby a v roku 1715 bola definitívne asanovaná 


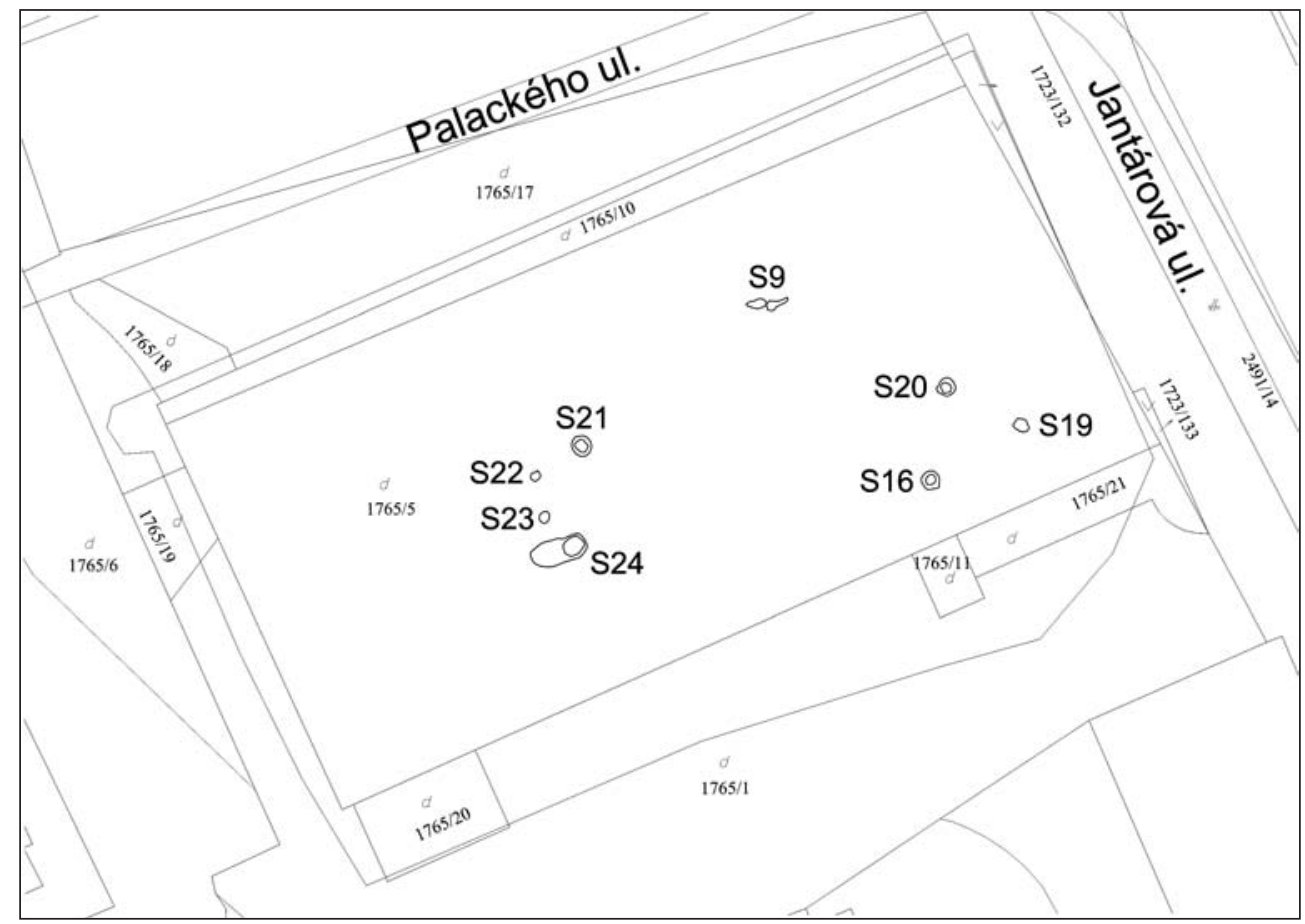

Obr. 2. Košice. Umiestnenie objektov v rámci stavebného pozemku na juhozápadnom nároží ulíc Palackého a Jantárovej.

(Orosová/Žažová 2011, 151-153). Predmestské osídlenie sa v týchto miestach v nasledujúcich desatročiach obnovilo (obr. 1). ${ }^{2}$ Nakol'ko sa jeho urbanistické usporiadanie vrátilo k podobe spred výstavby citadely je otázne. Vzhladom na rozsah zemných prác spojených s výstavbou i asanáciou tak rozsiahlej stavby sa možnost obnovy pôvodnej sídliskovej štruktúry javí ako málo pravdepodobná. K takýmto úvahám snád' podnecuje fakt, že nové usporiadanie nepôsobí koncepčným dojmom, má viac živelný charakter. Treba však pripustit, že situáciu mohla spôsobił existujúca cestná sieł a najmä korytá Čermel’ského potoka a Mlynského náhonu s jeho ramenami.

Novoobjavené pozostatky stredovekého a včasnonovovekého suburbánneho osídlenia súvisia s južným predmestím (obr. 1d). V letných mesiacoch roku 2017 sa uskutočnil archeologický výskum na juhozápadnom nároží Palackej a Jantárovej ulice. Výskum realizovaný Fakultou umení Technickej Univerzity v Košiciach bol počas stavebných prác na kancelárskom komplexe Duett Business Residence. Mal teda najmä záchranný charakter, kedže stavbe predchádzala príprava rozsiahlej stavebnej jamy za pomoci masívnych mechanizmov. Výkopové práce boli s požiadavkami archeologického výskumu zosúladené tak, že k skrývke plochy dochádzalo postupne v troch híbkových úrovniach kultúrnej vrstvy, čo umožnilo preskúmat relikty osídlenia z rôznych časových období. Prvá z úrovní sa nachádzala tesne pod niveletou súčasného okolitého terénu ${ }^{3} \mathrm{v}$ híbke $20-60 \mathrm{~cm}$. Druhá híbková úroveň sa nachádzala približne $120-160 \mathrm{~cm}$ pod tou súčasnou (asi 203,0 m n. m.) a tretia ešte o 110-140 cm nižšie (201,4-201,9 m n. m.). Najviac nálezov pochopitelne patrilo pozostatkom poslednej fázy osídlenia pôvodného južného predmestia, ktorá sa v týchto miestach formovala od prvej polovice 18. stor. a pretrvala až do začiatku 70. rokov 20. stor. Išlo predovšetkým o murované tehlové a kamenné konštrukcie v prvej a čiastočne druhej híbkovej úrovni a pozostatky nemurovaných, jamových zásahov najmä v druhej híbkovej úrovni. Skromné pozostatky včasnonovovekých a stredovekých sídelných stôp sa s jedinou výnimkou našli až v tretej híbkovej úrovni (obr. 2).

2 Na spomínanej, tzv. Pálfyho mape z roku 1742 je pomerne podrobne znázornené novo sformované predmestie s rozdelením parciel, obytnými domami a záhradami (obr. 1). Na pláne z roku 1747 (OrosoválŽažová 2011, 152) je však v týchto miestach vyznačený ešte obrys asanovanej citadely, ktorej bývalý areál je zatial’ skromne obsadený vznikajúcimi záhradami. Osídlenie východne od areálu pevnosti sa už svojou štruktúrou blíži stavu zobrazenému na Pálfyho mape, znázornených domov je však výrazne menej.

3 Výškové úrovne súčasného terénu pri jednotlivých rohoch stavebnej jamy mali nasledovné údaje: SZ roh - 204,287 m n. m.; SV roh - 204,774 m n. m.; JV roh - 204,607 m n. m.; JZ roh - 203,101 m n. m. 


\section{KATALÓG OBJEKTOV A NÁLEZOV}

\section{Situácia 9}

Objekt sa našiel v druhej úrovni postupného strojového výkopu plochy stavby. Na nehomogénnom podklade sa vyrysoval ako prepojenie dvoch nálezových situácií hnedo sfarbeného oválu a do červena prepáleného kruhového výseku, ktorý sa čiastočne strácal za ešte nezarovnaným terénom (obr. 3). Po čiastočnom preskúmaní nie je isté, či spomenuté situácie spolu súviseli. Jedna $\mathrm{z}$ nich, hnedý ovál, bola bez nálezov. Druhá, ktorá môže byt๋ pozostatkom dočasného ohniska, poskytla nepočetný nálezový súbor. Po čiastočnom odkrytí a zdokumentovaní situácie 9 si priebeh prác na stavbe vyžiadal pozornost’ na inom mieste plochy. Medzitým však situáciu 9 zničili tažké mechanizmy, a tak ju už nebolo možné doskúmat'.

\section{Nálezy}

1. Keramika: 11 črepov z nádob. 1 okraj (tab. I: 12) a 10 črepov z tiel nádob (7 režných, 4 glazované).

2. Stavebná keramika: dva malé fragmenty výmazu.

3. Zvieracie kosti: štyri zvieracie kosti nesúce stopy varenia.

\section{Situácia 16 , studňa 1}

Objekt sa našiel v tretej úrovni postupného strojového výkopu plochy stavby (300-320 cm od súčasného povrchu). Po začistení kruhového kamenného venca bolo zjavné, že ide o studňu. Šírka kamenného venca dosahovala $155-165 \mathrm{~cm}$, vnútorná svetlost' bola približne $85 \mathrm{~cm}$. Vnútorný priestor objektu, studne, bol následne postupnými krokmi odkrytý až na úroveň pevného štrkového podložia (obr. 4; 5). Zásyp tvorila stavebná sut', pozostávajúca $\mathrm{z}$ lomových kameňov v štrkovo-hlinitom prostredí. Kamenný plášt studne bol murovaný z nasucho kladených rozmerných lomových kameňov. Zachoval sa do híbky asi $70 \mathrm{~cm}$ od úrovne zachytenia, pozostávajúc z približne 7-8 radov kameňov. Plášt studne sa smerom od vrchného venca $\mathrm{k}$ spodnému mierne zužoval. Pod spodným vencom kameňov bol zachytený negatív drevenej rámovej konštrukcie štvorcového tvaru. Steny pôvodného rámu sa dobre črtali v pevnom štrkovom podloží, spráchnivená drevená múčka i drobné kusy nezotletej dreviny boli súčastou zásypu studne v jej najspodnejšej časti. Pod spodnou úrovňou pôvodného rámu sa už nachádzalo iba do štrku plytko preliačené dno.

\section{Nálezy}

1. Keramika: z odkrývania objektu pochádza 163 keramických črepov z nádob a jedna takmer v celku rekonštruovaná nádoba (tab. I: 7). 141 črepov bolo režných, 22 glazovaných. Glazúra mala výlučne zelené odtiene a bola aplikovaná zvnútra nádob, iba $\mathrm{v}$ jedinom prípade $\mathrm{z}$ oboch strán. 19 črepov patrilo okrajom nádob (tab. I: 5), sedem fragmentov dnám nádob so stopami po zrezaní strunou (tab. I: 4, 7). 134 črepov pochádzalo z tiel nádob, tri fragmenty z pásikových úch.

2. Stavebná keramika: jeden nevel'ký fragment keramického korýtka (tab. I: 6) a tri malé fragmenty tehly bez jediného meratelného rozmeru.

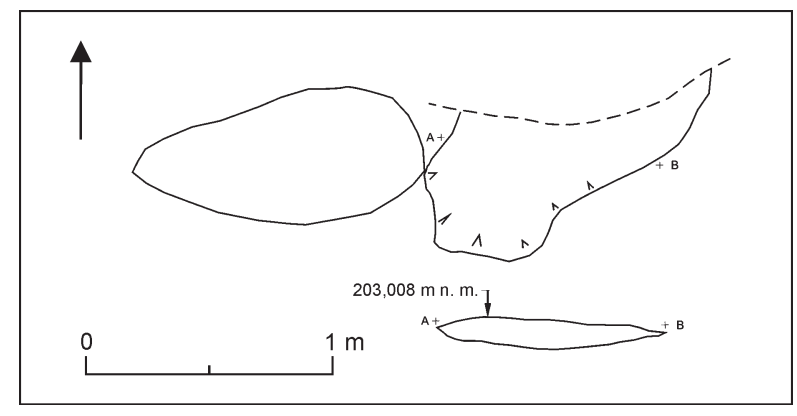

Obr. 3. Košice, Duett. JZ nárožie Palackého a Jantárovej ul. Situácia 9 (pôdorys; rez Z - V). Kresba R. Rusnák.

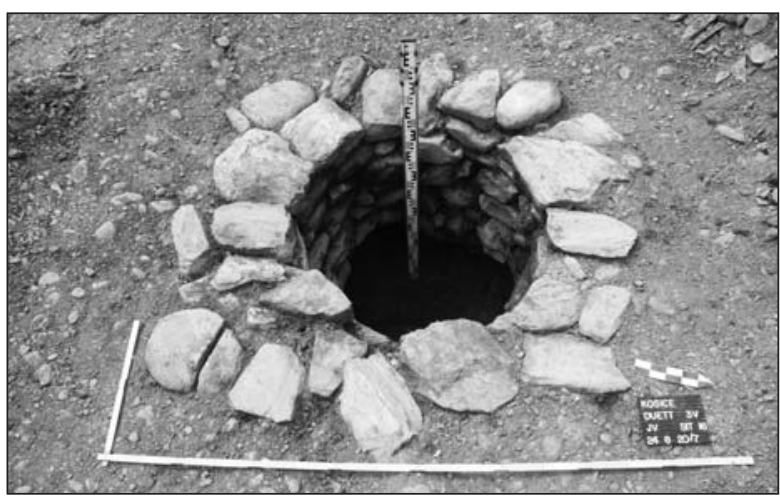

Obr. 4. Košice, Duett. JZ nárožie Palackého a Jantárovej ul. Situácia 16 - studňa 1. Autor fotografie R. Rusnák.

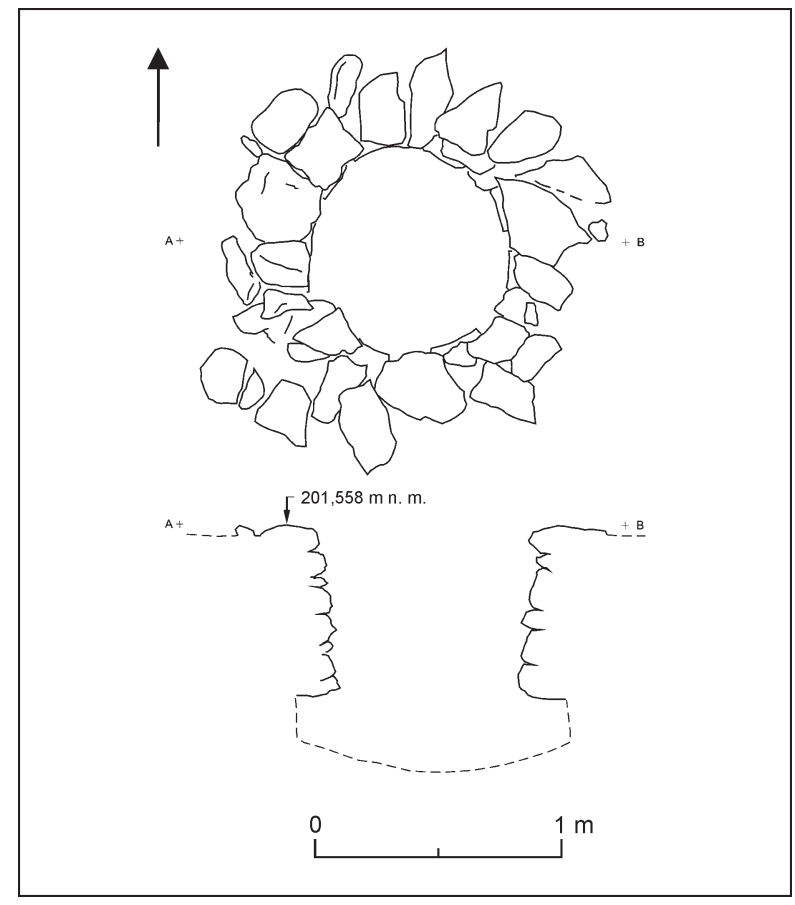

Obr. 5. Košice, Duett. JZ nárožie Palackého a Jantárovej ul. Situácia 16 (pôdorys; rez J - S). Kresba R. Rusnák. 
3. Kovové predmety: jeden dobre zachovaný železný náprstok (tab. I: 1); malá čast̉ rukoväte, pravdepodobne noža so železným jadrom a dreveným obložením spojeným medeným nitom (tab. I: 2); tri fragmenty železných predmetov (klinec, čepel’ noža, železný pás - čepel??).

4. Kostené predmety: čast' kostenej suroviny na výrobu gombíkov s piatimi celými a jedným čiastočným kruhovým prierezom (tab. I: 3). Priemer negatívu gombíkov je 1,2 cm.

5. Zvieracie kosti: jedna kost’ so stopami po varení.

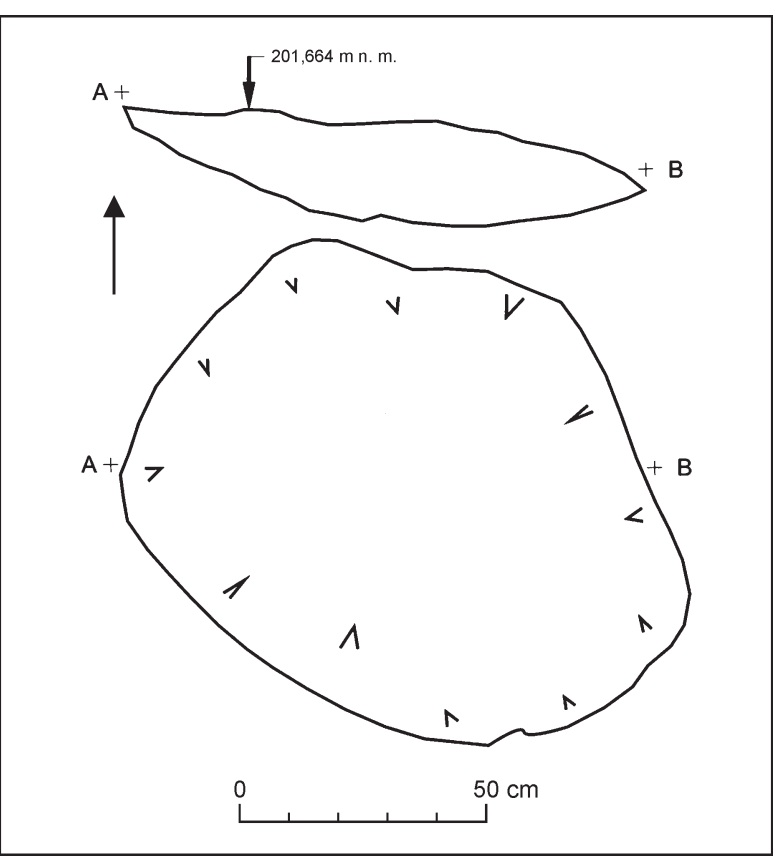

Obr. 6. Košice, Duett. JZ nárožie Palackého a Jantárovej ul. Situácia 19 (pôdorys, rez Z - V). Kresba R. Rusnák.

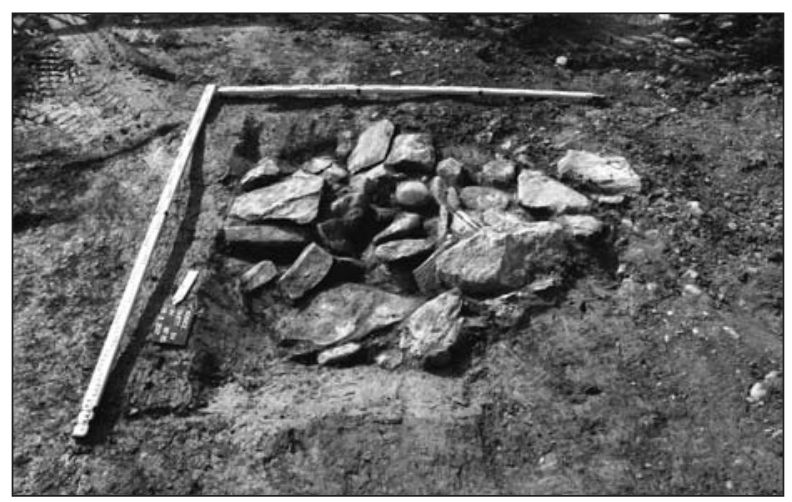

Obr. 7. Košice, Duett. JZ nárožie Palackého a Jantárovej ul. Kamenný zával nad situáciou 20 - studňou 2. Foto R. Rusnák.

\section{Situácia 19}

Plytký jamový objekt nepravidelného, pôvodne však pravdepodobne kruhového či oválneho tvaru (obr. 6). Nepravidelný tvar bol spôsobený posunom výplne pod tlakom zubov lyžice mechanizmu pri strojovej skrývke plochy. Objekt sa našiel v tretej úrovni postupného odkrývania plochy stavby. Bol rozpoznaný vd’aka tmavšej výplni na svetlohnedom podklade okolia. Pôvodný ovál mal dížku približne $135 \mathrm{~cm}$, šírku $125 \mathrm{~cm}$ a max. híbka objektu od úrovne nájdenia bola $21 \mathrm{~cm}$.

\section{Nálezy}

1. Keramika: 21 črepov z nádob. Všetky režné. dva okraje (tab. I: 10, 11), dve dná zrezané strunou, jeden fragment pokrievky s gombíkovitým držadlom (tab. I: 8), 19 črepov z tiel nádob (tab. I: 9).

2. Stavebná keramika: dva menšie fragmenty tehly. Iba $\mathrm{v}$ jednom prípade jeden meratelný rozmer, hrúbka $5,1-5,2 \mathrm{~cm}$. Jeden malý fragment škridly s hrúbkou $1,9 \mathrm{~cm}$; osem fragmentov hlineného výmazu.

3. Zvieracie kosti: štyri zvieracie kosti.

\section{Situácia 20, studňa 2}

Objekt sa našiel v tretej úrovni postupnej strojovej skrývky plochy stavby, v nevel'kej vzdialenosti od situácií 16 a 19. Stav mal charakter kamenného závalu približne oválneho tvaru (obr. 7). Po d’alšom začistení sa vyprofiloval vrchný veniec studne. Šírka kamenného venca dosahovala 150-160 cm, vnútorná svetlost’ bola približne $85 \mathrm{~cm}$. Vnútorný priestor objektu, studne, bol postupnými krokmi odkrytý až na úroveň pevného štrkového podložia (obr. 8; 9). Zásyp tvorila stavebná sut', ktorá pozostávala z lomových kameňov v štrkovo-hlinitom prostredí. Kamenný plášt studne bol murovaný z nasucho kladených rozmerných lomových kameňov. Zachoval sa do híbky asi $65 \mathrm{~cm}$ od úrovne zachytenia a pozostával z približne 7-9 radov kameňov. Plášt’ studne sa smerom od vrchného venca k spodnému nezužoval, ale zvislo klesal. Pod spodným vencom kameňov sa v relatívne dobrom stave nachádzala drevená rámová konštrukcia štvorcového tvaru. Približne $20 \mathrm{~cm}$ pod spodnou úrovňou rámu sa už nachádzalo iba do štrku plytko preliačené dno.

Po definitívnom odkrytí a zdokumentovaní objektu bola celá hmota kamenného plášta studne odstránená, aby bolo možné detailne zdokumentovat spodnú rámovú konštrukciu (obr. 10). Tá bola tvorená štyrmi, približne $1 \mathrm{~m}$ dlhými drevenými trámami, v nárožiach vyhlobenými a spojenými masívnymi železnými nitmi. Priestor za východnou a západnou stenou rámu bol vystužený vel'kými plochými lomovými kameňmi. Po zdokumentovaní bola celá rámová konštrukcia odobratá. Z dvoch lepšie zachovaných trámov boli získané vzorky pre dendrochronologickú analýzu. Použitou drevinou je dub, pričom strom bol zot’atý niekedy po roku 1576 (Kyncl 2018).

\section{Nálezy}

1. Keramika: z odkrývania objektu pochádza 87 črepov z nádob, z toho štyri okraje, jeden väčší fragment taniera (tab. II: 6), jeden malý okraj pokrievky; osem dien (z toho dve zrezané strunou); 70 črepov z tiel nádob (tab. II: 2-5); tri fragmenty úch. Väčšia čast̉ črepov je glazovaná, prípadne zdobená malovaním. 31 črepov je režných a na pohlad pôsobí neskorostredoveko. 


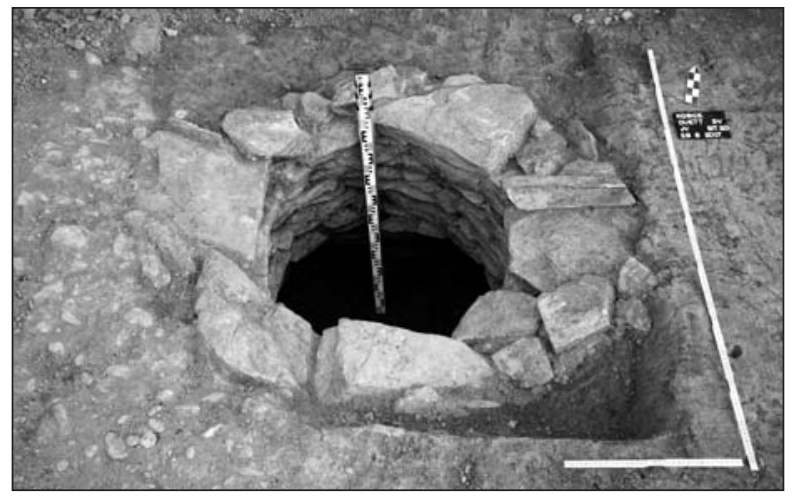

Obr. 8. Košice, Duett. JZ nárožie Palackého a Jantárovej ul. Situácia 20 - studňa 2. Foto R. Rusnák.

2. Stavebná keramika: osem väčších fragmentov tehál s dvoma meratelnými rozmermi (tab. III: 1-4): 1 - š: $17 \mathrm{~cm}$, hr. 4,5cm; 2 - š: 16 cm, hr. 5,1 cm (hrubšia, viditelné väčšie kamienky v hmote); 3 - š: $11 \mathrm{~cm}$, hr. 5,5 cm (výrazne slinutá); $4-$ š. $10,8-11 \mathrm{~cm}$, hr. 4,4-4,7 cm (značne slinutá so stopami po forme); 5 š: 13,4 cm, hr. 5,5-5,6 cm; 6 - š. 16,1 cm, hr. 4,2 cm; 7 š: $11,2-11,5 \mathrm{~cm}$, hr. $4,5 \mathrm{~cm}$ (slinutá, na jednej strane so stopami po forme a úprave); $8-$ š. $14 \mathrm{~cm}, \mathrm{hr} .6,1 \mathrm{~cm}$ (na jednej strane náznak značky? - pretlačený pásik; tab. III: 3). 16 menších fragmentov tehál s jedným meratelným rozmerom - hrúbkou: $1-5,3 \mathrm{~cm} ; 2-7,2 \mathrm{~cm}$; $3-5,8 \mathrm{~cm}$ (trochu slinutá); $4-6,8 \mathrm{~cm} ; 5-4,7 \mathrm{~cm} ; 6-$ $5,2 \mathrm{~cm} ; 7-4,6-4,7 \mathrm{~cm} ; 8-4,6 \mathrm{~cm} ; 9-4,5 \mathrm{~cm}(7-9$ môžu patrit' pôvodne jednej tehle); 10 - 4,5 cm; 11 $7,3 \mathrm{~cm} ; 12-4,5 \mathrm{~cm} ; 13-4,6 \mathrm{~cm} ; 14-4,4 \mathrm{~cm}$ (slinutá); $15-4,2-4,4 \mathrm{~cm} ; 16-5,1 \mathrm{~cm} .13$ menších fragmentov tehál bez meratel'ného rozmeru. 36 drobných amorfných fragmentov, z ktorých čast’ pravdepodobne patrí pozostatkom tehál a čast' pozostatkom výmazu. Dva malé fragmenty škridly.

3. Kovové predmety: fragment železného kolesa (priemer $21,5 \mathrm{~cm}$ ) z pásového plechu so štyrmi lúčmi, ktoré pozostávali z dvoch prekrížených pásov (tab. II: 7); jeden fragment železnej sekery s čiastočne zachovanou čepelou, v tulajke ešte s častou dreveného poriska (tab. II: 8); 21 menších neošetrených železných predmetov - jeden väčší pásový plech (podkova?; tab. II: 9); jedna malá čast' podkovy; v jednom prípade zo zvinutého plechu vytvorená tulajková násada s jednou stranou zúženou do špica; dva pliešky; 10 klincov, zvyšok drobné amorfné kusy.

4. Mince: štyri tzv. polturáky, 1,5 groše (tab. II: 1). Ide o dve rôzne pol'ské razby Žigmunda III.

5. Zvieracie kosti.

\section{Situácia 21, studňa 3}

Objekt sa odkryl v tretej úrovni postupnej strojovej skrývky plochy stavby, v nevel'kej vzdialenosti od situácií 22 až 24 . Hned' po nájdení sa vyprofiloval vrchný veniec studne. Šírka kamenného venca dosahovala 150-160 cm, vnútorná svetlost’ bola približne $85 \mathrm{~cm}$. Vnútorný priestor objektu, studne, bol postupnými krokmi odkrytý až na úroveň pevného štrkového podložia (obr. 11; 12). Zásyp tvorila stavebná sut', ktorá pozostávala z lomových kameňov v štrkovo-hlinitom prostredí. Kamenný plášt’ studne bol murovaný z nasucho kladených rozmerných lomových kameňov. Zachoval sa do híbky okolo $75 \mathrm{~cm}$ od úrovne zachytenia a pozostával z približne 6-8 radov kameňov. Plášt studne sa smerom od vrchného venca k spodnému nezužoval, ale zvislo klesal. Pod spodným vencom kameňov sa našiel negatív drevenej rámovej konštrukcie štvorcového tvaru.
Obr. 9. Košice, Duett. JZ nárožie Palackého a Jantárovej ul. Situácia 20 (pôdorys; rez Z - V; pôdorys rámovej konštrukcie). Kresba R. Rusnák.

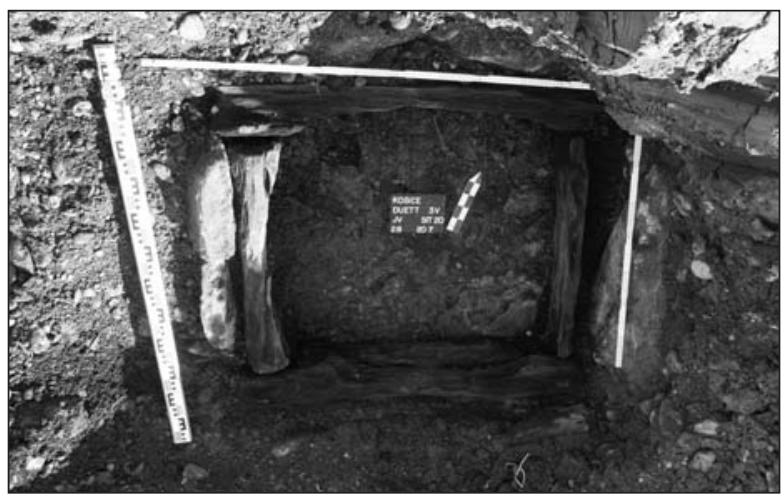

Obr. 10. Košice, Duett. JZ nárožie Palackého a Jantárovej ul. Rámová konštrukcia situácie 20 - studne 2 po odstránení kamenného plášta studne. Foto R. Rusnák. 


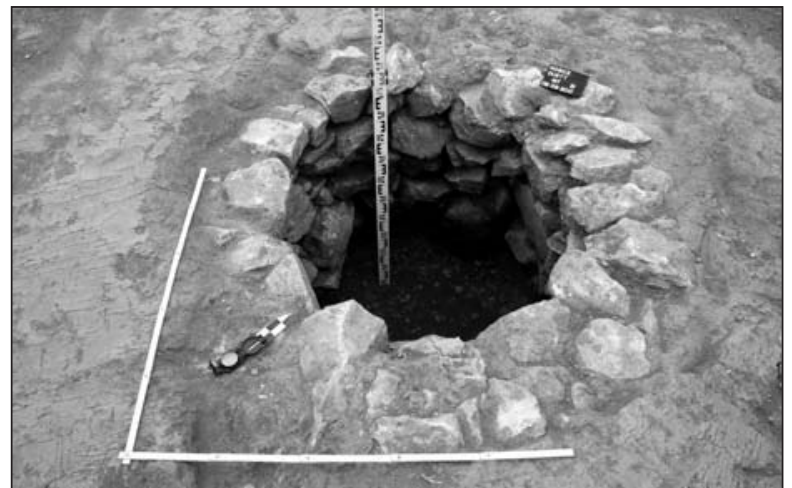

Obr. 11. Košice, Duett. JZ nárožie Palackého a Jantárovej ul. Situácia 21 - studňa 3. Foto A. Balogh.

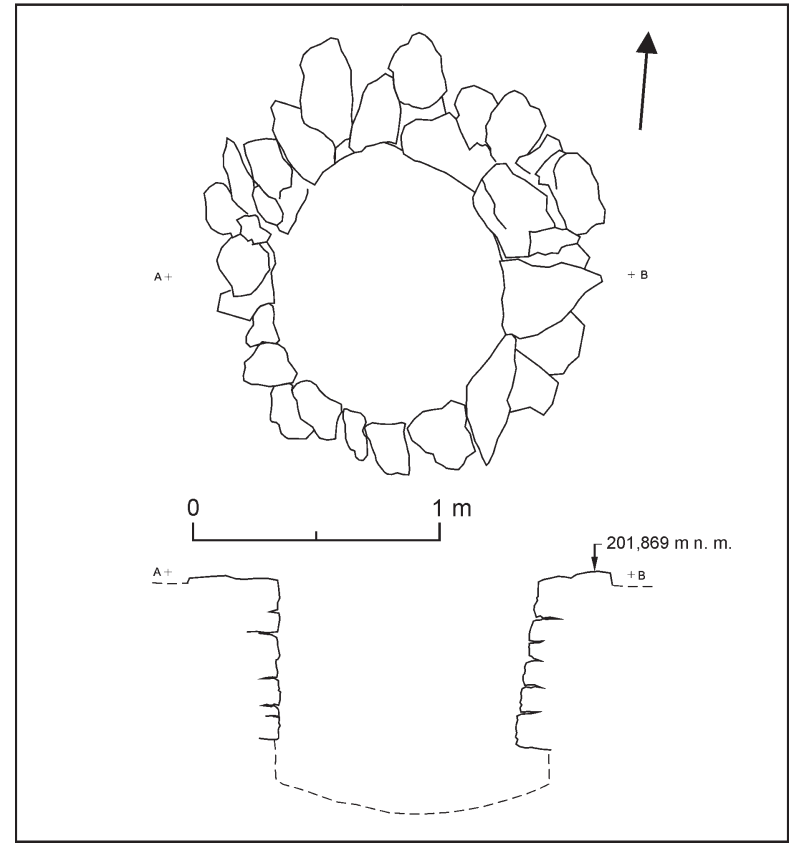

Obr. 12. Košice, Duett. JZ nárožie Palackého a Jantárovej ul. Situácia 21 (pôdorys; rez Z - V). Kresba R. Rusnák.

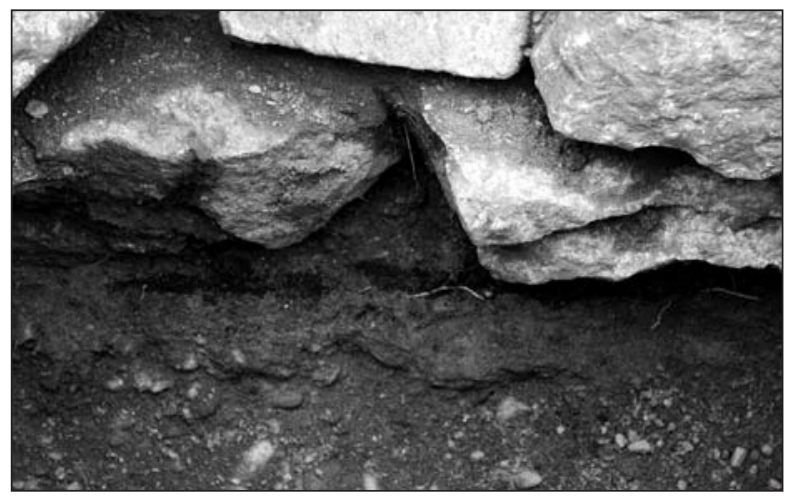

Obr. 13. Košice, Duett. JZ nárožie Palackého a Jantárovej ul. Negatív rámovej konštrukcie ešte so stopami práchnivého dreva pod kamennou konštrukciou situácie 21 - studne 3. Foto A. Balogh.
Steny pôvodného rámu sa dobre črtali v pevnom štrkovom podloží (obr. 13), spráchnivená drevená múčka bola súčastou zásypu studne $\mathrm{v}$ jej najspodnejšej časti. Pod spodnou úrovňou pôvodného rámu sa už nachádzalo iba do štrku plytko preliačené dno.

\section{Nálezy}

1. Keramika: 28 črepov $\mathrm{z}$ nádob, $\mathrm{z}$ toho 12 črepov pochádza z jednej nádoby (tab. IV: 1); Jeden výraznejší črep s červeným malovaním (tab. IV: 2); jedno dno z neskorostredovekej nádoby; jedna nôžka z trojnohej panvice (tab. IV: 3).

2. Kachlice: 19 fragmentov komorových kachlíc. 16 ks pochádza z čelných vyhrievacích stien, tri z bočných stien kachlíc. Devät fragmentov čelných vyhrievacích stien je glazovaných (osem kusov má zelený odtieň, jeden je polychrómia); sedem je režných. Jeden fragment nesie figurálny biblický motív a čast nápisu ABRAHAM (tab. IV: 4); 13 ks má rôzne tapetové vzory s geometricko rastlinným ornamentom (tab. IV: 5-7; V: 4); dva fragmenty rohových kachlíc (tab. $\mathrm{V}: 3)$.

3. Stavebná keramika: štyri väčšie fragmenty tehál s dvoma meratel'nými rozmermi (tab. V: 6, 7): 1 - š: $15,2 \mathrm{~cm}$, hr. 5,5 cm (aj väčšie kamienky v hmote); 2 š: 13,5 cm, hr. 5,4-5,7 cm (na jednej strane viditelné pracovné stopy - zarovnávanie plochým nástrojom); 3 - š: 13,9 cm, hr. 6,3 cm; 4 - š. 15,9 cm, hr. 6,3 cm (na jednej strane stopy úprav - neúplné, málo precízne). 11 menších fragmentov tehál s jedným meratelným rozmerom, hrúbkou: $1-4,4 \mathrm{~cm}$ (neúplná úprava); $2-4,8 \mathrm{~cm} ; 3-4,5 \mathrm{~cm} ; 4-4,9 \mathrm{~cm}$ (precízna úprava a zarovnanie); $5-4,7 \mathrm{~cm}$ (precízna úprava a zarovnanie); 6 - 5,6 cm (precízna úprava a zarovnanie); $7-4,7 \mathrm{~cm}$ (neúplná úprava); $8-4,9 \mathrm{~cm}$ (prstovka; tab. V: 7); $9-4-4,1 \mathrm{~cm} ; 10-5 \mathrm{~cm} ; 11-4,9 \mathrm{~cm}$. Dva menšie fragmenty tehál bez meratel'ného rozmeru. Jeden fragment dlaždice s rovnými hranami: š: $19,1 \mathrm{~cm}, \mathrm{hr}$. $4,4 \mathrm{~cm}$. Povrch dlaždice je vyhladený (tab. V: 5).

4. Zvieracie kosti: početný súbor zvieracích kostí, zatial' bez bližšej druhovej analýzy.

\section{Situácia 22}

Menší jamový objekt sa našiel v tretej úrovni postupnej strojovej skrývky plochy stavby, v nevel'kej vzdialenosti od situácií 21, 23 a 24 (obr. 14). Išlo o plytký objekt kruhového pôdorysu s priemerom približne $75 \mathrm{~cm}$ a max. híbkou $19 \mathrm{~cm}$. Steny sa príkro zvažovali do mierne preliačeného dna.

\section{Nálezy \\ Objekt bol bez nálezov.}

\section{Situácia 23}

Menší jamový objekt bol objavený v tretej úrovni postupnej strojovej skrývky plochy stavby, v nevel'kej vzdialenosti od situácií 21, 22 a 24 (obr. 15). Išlo o objekt kruhového pôdorysu s priemerom asi $80 \mathrm{~cm}$ a max. híbkou $33 \mathrm{~cm}$. Steny sa príkro zvažovali do mierne preliačeného dna.

\section{Nálezy}

Objekt bol bez nálezov. 


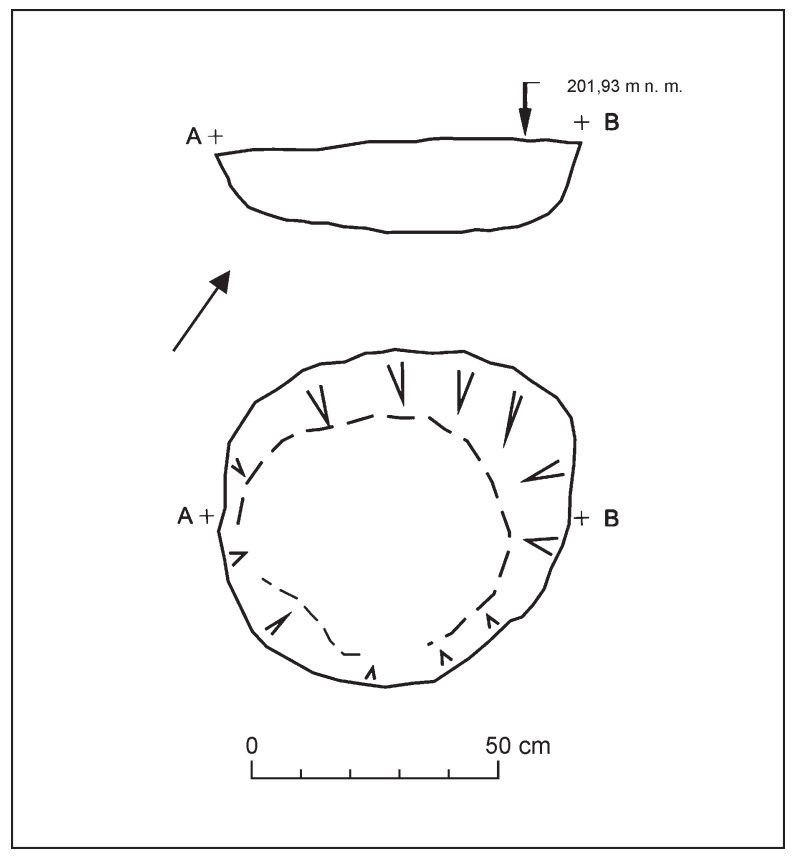

Obr. 14. Košice, Duett. JZ nárožie Palackého a Jantárovej ul. Situácia 22 (pôdorys; rez JZ - SV). Kresba R. Rusnák.

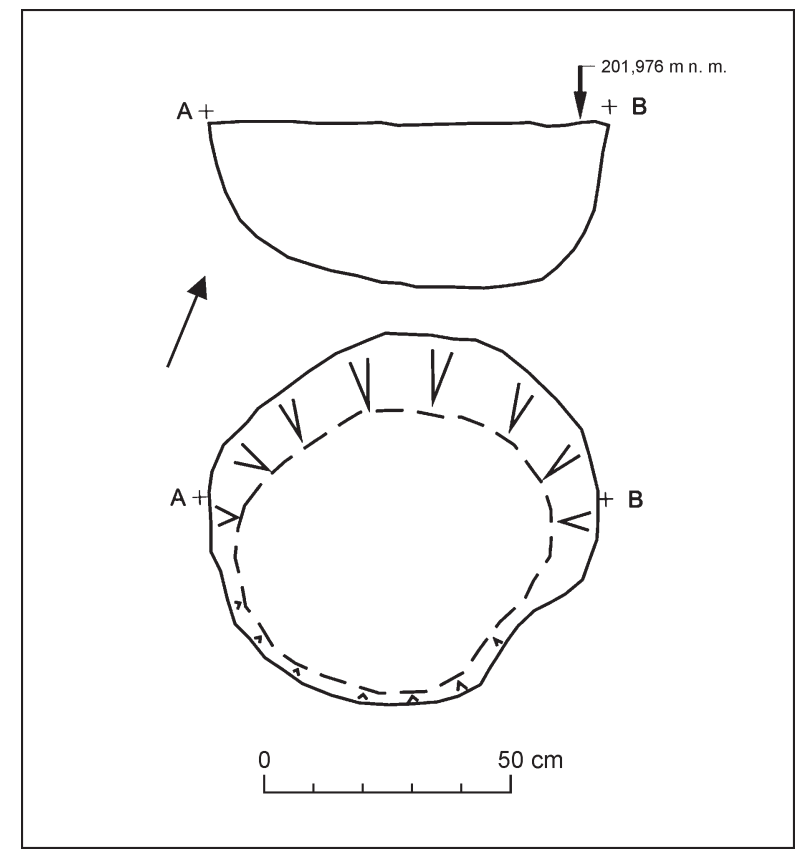

Obr. 15. Košice, Duett. JZ nárožie Palackého a Jantárovej ul. Situácia 23 (pôdorys, rez JZ - SV). Kresba R. Rusnák.

\section{Situácia 24}

Rozmerný jamový objekt sa našiel v tretej úrovni postupnej strojovej skrývky plochy stavby, v nevel'kej vzdialenosti od situácií 21 až 23 (obr. 16). Objekt mal pravidelný oválny tvar s dlhšou osou $460 \mathrm{~cm}$ a kratšou max. 207 cm. Väčšia čast’ objektu bola plytká s híbkou nepresahujúcou $17 \mathrm{~cm}$. Vo východnej časti objektu sa nachádzalo výraznejšie zahíbenie približne kruhového tvaru s priemerom 130-140 cm. Steny zahĺbenej časti sa príkro až kolmo, miestami kónicky zvažovali do takmer rovného dna.

\section{Nálezy}

1. Keramika: 151 črepov z nádob; dve časti pravdepodobne jednej nádoby, väčšieho hrnca s uchom (tab. VI: 1). Hrniec je režný s červeným mal'ovaním. 42 d’alších menších črepov môže patrit k tejto nádobe, prípadne inej, rovnakého typu. Pomer glazovaných a neglazovaných črepov vo zvyšku súboru je polovičný. 12 okrajov (tab. VII: 2-6; 8, 9, 11, 12); 19 dien (v jednom prípade stopy zrezania strunou); jeden tanier čiastočne rekonštruovatel’ný (tab. VII: 1); tri uchá (tab. VII: 7, 10).

2. Kachlice: 13 fragmentov bočných stien kachlíc.

3. Stavebná keramika: dva fragmenty tehál s dvomi meratel’nými rozmermi (tab. VI: 4, 5): 1 - š: $12,6 \mathrm{~cm}, \mathrm{hr}: 5,4 \mathrm{~cm} ; 2$ - š: 12,4 cm, hr: 4,6-5 cm; dva fragmenty tehál s jedným meratelným rozmerom, hrúbkou: 1 - 5,1 cm (mierne slinutá); 2 -3,6-4,1 cm (výrazne slinutá, zdeformovaná); jeden fragment tehly bez meratel'ného rozmeru.

4. Kovové predmety: jeden fragment železnej podkovy (tab. VI: 3); jeden železný klinec (tab. VI: 2).

5. Zvieracie kosti: početný súbor zvieracích kostí bez bližšej druhovej analýzy.

\section{OSÍDLENIE}

Záchranný archeologický výskum na juhozápadnom nároží Palackého a Jantárovej ulice objavil osem objektov, ktoré je možné dat' do súvisu s osídlením južného predmestia pred rokom 1671. V šiestich prípadoch objekty datujú nálezy z ich výplne, $\mathrm{v}$ dvoch prípadoch ide len o predpoklad na základe horizontálnej stratigrafie. Tri objekty možno datovat’ do obdobia neskorého stredoveku (situácie 9, 16, 19) a pät objektov do obdobia včasného novoveku (situácie 20-24). Typologická škála objektov nie je vel'mi široká. Štyri jednoduché zemné jamové objekty, jedno ohnisko a tri studne. Pri jamových objektoch išlo v troch prípadoch o plytké objekty približne kruhového pôdorysu s priemerom okolo $100 \mathrm{~cm}$ (situácie 19, 22, 23). Dva z nich boli bez nálezov. Rozlahlý a v jednej časti zahĺbený jamový objekt, situácia 24, by snád’ bolo možné dat do súvisu so živočíšnou výrobou domového hospodárstva. Naznačuje to početné zastúpenie kostí najmä väčších domácich zvierat. Stopy ohňa, prípadne iné konštrukčné prvky ako napr. kolové 


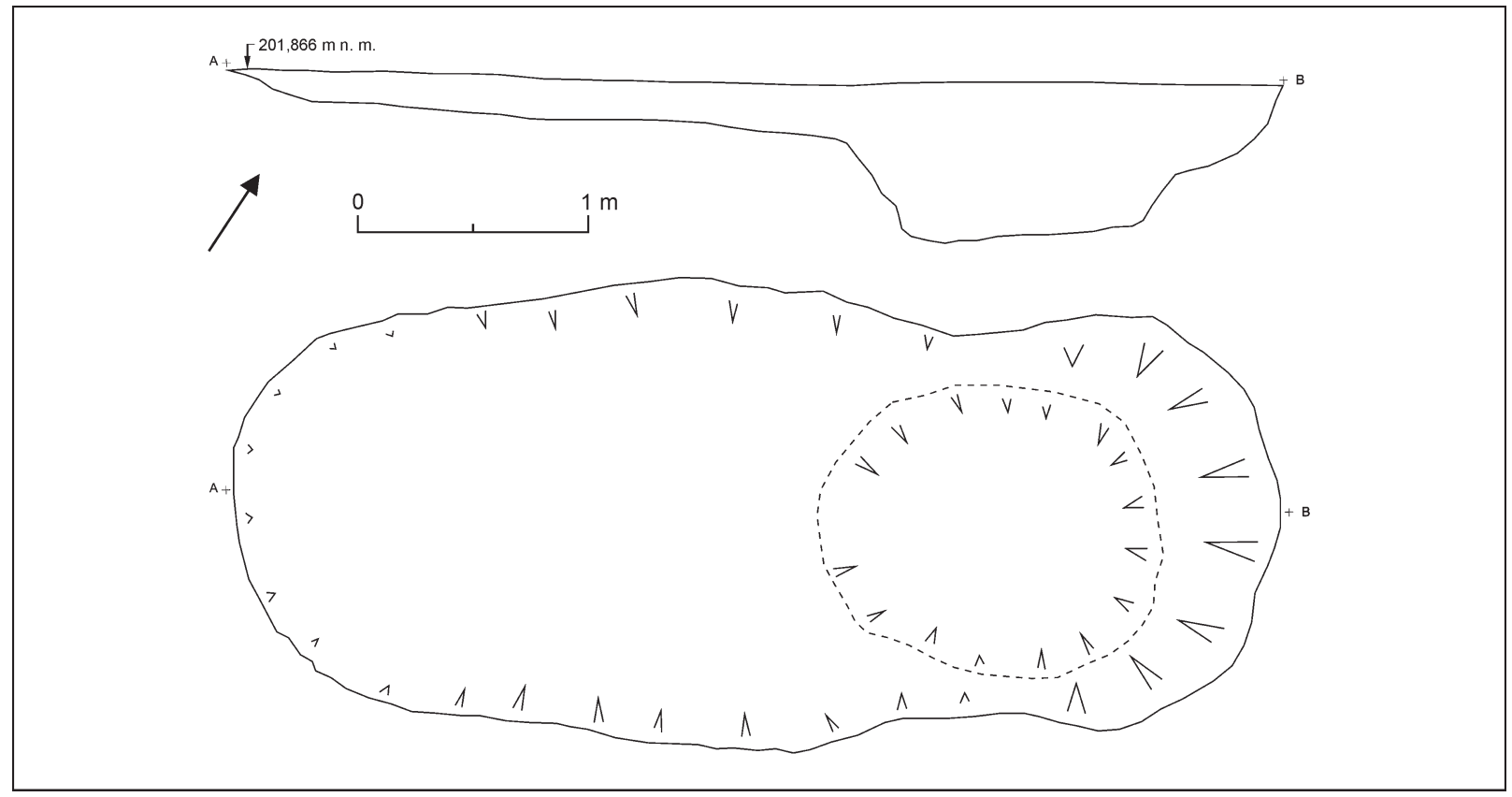

Obr. 16. Košice, Duett. JZ nárožie Palackého a Jantárovej ul. Situácia 24 (pôdorys; rez JZ - SV). Kresba R. Rusnák.

jamy, sa nepodarilo nájstł. Vo všetkých prípadoch jamových objektov je nutné predpokladat', že išlo už iba o ich spodné časti. Mieru ich pôvodného zahĺbenia nepoznáme. Podla úrovne nájdenia (201,95-201,6 m n. m.) a zahíbenia blízkych studní však možno predpokladat’ výraznejšie zahĺbenie. Táto skutočnost', spolu so stavom ich zachovania, neponúka vel'ké možnosti interpretácie. Iba čiastočne preskúmaný objekt, situácia 9, je možné interpretovat ako dočasné exteriérové ohnisko. Tento objekt sa ako jediný našiel vo vyššej nivelete odkrývania (203,00 m n. m.).

Interpretačne jednoznačne a pre hodnotenie charakteru osídlenia najzaujímavejšie vyznievajú nálezy troch studní (situácie 16, 20, 21). Vo všetkých prípadoch možno konštatovat použitie rovnakých konštrukčných prvkov. Studne boli kruhového pôdorysu a boli budované z nasucho kladených lomových kameňov. Vonkajší priemer plášta kolísal medzi 150-165 cm, vnútorná svetloste činila približne $85 \mathrm{~cm}$. Iba v jednom prípade (situácia 16) sa vnútorný priestor studne od nájdenej koruny smerom ku dnu mierne zužoval. Pri zvyšných dvoch zvislo klesal. Vo všetkých prípadoch sa pod kamennou konštrukciou nachádzala ešte drevená rámová konštrukcia štvorcového tvaru. $V$ dvoch prípadoch sa zachovala už iba v negatíve (situácie 16, 21), v jednom prípade (situácia 20) bola zachovaná v relatívne dobrom stave. To umožnilo jej detailnejšiu dokumentáciu a poskytlo vzorky pre dendrochronologickú analýzu. Dná všetkých troch studní sa nachádzali mierne pod spodnou úrovňou dreveného rámu. Zachovali sa iba spodné časti studní, od úrovne odkrytia po dná dosahoval rozmer nájdenej stavebnej konštrukcie asi $100 \mathrm{~cm}$. Masívny strojový stavebný výkop sa pre potreby archeologického dohladu vykonával v dohodnutých úrovniach. Studne sa ešte v druhej úrovni výkopu (približne 203,00 m n. m.) nenašli, v tretej (201,88-201,42 m n. m.) už áno. Navyše v prípade situácie 20, studne 2, bol v úrovni zistenia pod nánosom svetlohnedej ílovitej hliny odkrytý kamenný zával (obr. 4) a až po jeho odstránení sa objavil vrchný veniec plášta studne. Možno teda konštatovat', že uvedený stav nespôsobili výkopové práce v roku 2017, ale udalosti v minulosti. Tie možno dat' do súvisu s rokom 1671, ked’ bolo celé južné predmestie asanované, aby uvol'nilo miesto výstavbe citadely. Rozmerné zemné násypy a priekopy si museli vyžiadał' masívne transfery zeminy a dá sa predpokladat', že všetok použitelný stavebný materiál bol využitý. Pre situáciu 20, studňu 2 a situáciu 21, studňu 3, možno považovat rok 1671 za pravdepodobný čas ich zániku. Dendrochronologický údaj získaný z rámovej konštrukcie situácie 20, studne 2 , zároveň umožňuje datovat i jej výstavbu, a to do obdobia po roku 1576. Výplň situácie 16, studne 1, poskytla iba chronologicky ucelený neskorostredoveký materiál. Studňa teda pravdepodobne zanikla ešte pred koncom 15. stor. Ako jedna z možností sa ponúka i súvislost’ so spomínanými udalostami z roku 1491. Všetky tri studne svojou stavebnou konštrukciou zapadajú do rámca doteraz známych dobových košických studní (Ďurišová 2013). 


\section{ROZBOR NÁLEZOV}

Obdobie neskorého stredoveku reprezentujú v nálezovom súbore artefakty, ktoré pochádzajú zo situácie 9, situácie 16, studne 1 a situácie 19. Neskorostredoveké nálezy, najmä keramiky, sú zastúpené ako menšinová zložka i v sortimente nálezov zo situácie 20, studňa 2 , situácie 21 , studňa 3 a situácie 24 . Tieto objekty však už svojimi nálezmi reprezentujú mladší včasnonovoveký horizont osídlenia. Keramickej náplni oboch chronologických stupňov sa v kontexte východného Slovenska naposledy zásadným spôsobom venoval M. Uličný $(2003 ; 2004 ; 2008), \mathrm{v}$ košickom prostredí obšírnejšie autor tohto článku (Rusnák 2009a; 2014). Nálezy stavebnej keramiky z Košíc a okolia spracoval najmä M. Čurný (2010; 2015). Košickým nálezom železných predmetov z oboch sledovaných období bola v ostatnom období tiež čiastočne venovaná pozornost' (Gašaj 2014; Rusnák 2009b).

\section{HORIZONT NESKORÉHO STREDOVEKU}

S výnimkou jednej rekonštruovatelnej nádoby je súbor neskorostredovekých keramických črepov skromný. Nádoba patrila režnému džbánku s uchom (tab. I: 7). Mal jednoducho vytiahnuté hrdlo s jemným obežným žliabkom tesne pod okrajom. Jeden jemný obežný žliabok sa nachádzal aj v mieste najväčšej vydutiny nádoby. Rozhranie hrdla a tela nádoby vymedzoval jemný plastický obežný veniec. Dno bolo zrezané strunou. Pásikové ucho bolo z vonkajšej strany výrazne pozdížne prežliabnuté. Nádoba bola vysoká $19,5 \mathrm{~cm}$ s priemermi okraja $8,3 \mathrm{~cm}$, dna $6,8 \mathrm{~cm}$ a najväčšej vydutiny $10,9 \mathrm{~cm}$. Vo väčšine prípadov zachovaných okrajov išlo o tenkostenné, zväčša jednoducho vytiahnuté okraje stolovej keramiky, určenej predovšetkým na uskladnenie či pitie tekutín (tab. I: 5). I črepy z tiel nádob boli z vel'kej väčšiny tenkostenné. Žiadny z keramických črepov nevybočoval z bežného rámca doteraz známej neskorostredovekej keramiky z prostredia Košíc.

Za pozornost' stojí nález fragmentu korýtka, ktoré je s vel'kou pravdepodobnostou pozostatkom strešnej krytiny (tzv. mních, prípadne hrebenáč), aj ked’ nemožno celkom vylúčit možnost', že ide o pozostatok segmentu žlabového potrubia. Rozmery fragmentu indikujú pomerne masívny exemplár s hranou hrubou 2,1 cm, v mieste najhrubšieho lomu až 3,3 cm. Predpokladaná šírka pôvodného nálezu bola v týchto miestach približne $18 \mathrm{~cm}$. Našlo sa i viacero malých fragmentov tehál a fragmenty hlineného výmazu. Jeden fragment gotickej tehly, tzv. prstovky, pochádza aj zo studne 3 (tab. V: 7).

Nálezy dobre zachovaného železného náprstku (tab. I: 1), časti rukoväte noža s dreveným obložením (tab. I: 2) či kostenej suroviny na výrobu gombíkov (tab. I: 3) zo studne 1, mierne vyčnievajú z inak nevýraznej kolekcie neskorostredovekých nálezov. Svojim stvárnením a charakterom však nijako nevybočujú $\mathrm{z}$ rámca daného typu sortimentu.

\section{HORIZONT VČASNÉHO NOVOVEKU}

Získaná kolekcia včasnonovovekej keramiky z lokality je málopočetná a dá sa povedat', že aj málo reprezentatívna. Rekonštruovatelných nádob je minimum (tab. VI: 1), zväčša ide iba o menšie črepy. Dostatočne však dokladá druhovú i výzdobnú rozmanitost̉ keramickej produkcie, ktorú so sebou včasný novovek priniesol. Zastúpená je kuchynská a stolová keramika, režné nádoby zdobené červeným mal'ovaním (tab. IV: 2) i polychrómiou (tab. II: 3-5), rôzne glazovaná keramika či ludová fajansa (tab. II: 2).

Súbor fragmentov renesančných kachlíc zo zásypu studne 3 vyznieva zaujímavo i ako podnet $\mathrm{k}$ úvahám o kvalite bývania na košických predmestiach v období včasného novoveku. Viacero druhov kachlíc s tapetovými motívmi dopĺn̆a fragment kachlice s figurálnym výjavom, ktorý je doplneným nápisom (tab. IV: 4). Kachlica má tmavozelenú glazúru. Zo zobrazenej figúry sa dochovala iba spodná čast' nohy. Zachovaná čast’ nápisu „ABRAH“ celkom jednoznačne poukazuje na starozákonný motív Abraháma a Izáka. Vd’aka prakticky identickej analógii z ned’alekého hradu Füzér (Chovanec et al. 1996, 29) si možno spravit jasnú predstavu o stvárnení košického nálezu. Postava muža v renesančnom odeve stojí nad klačiacim dietatom a v jednej ruke má nôž. Výjav má klasické renesančné architektonické rámovanie v podobe zdobenej niky a dopĺn̆a ho nápis „ABRAHAMISAK“. Kachlica z hradu Fűzér je datovaná do roku 1562 (Gruia 2013, 323). Zvyšné fragmenty kachlíc nesú rôzne tapetové vzory so štylizovaným geo- 
metricko rastlinným ornamentom (tab. IV: 5-7; V: 4). Sú režné alebo zeleno glazované. V jednom prípade je glazúra polychrómna, zelená a žltá (tab. IV: 7). Sú medzi nimi aj dva fragmenty rohových kachlíc s pásovými vzormi listovca a povrazca (tab. V: 3 ).

Pomerne početné sú tiež nálezy stavebnej keramiky. Ide predovšetkým o fragmenty tehál, zastúpená je i škridlicová strešná krytina a v jednom exempláre aj dlaždica (tab. V: 5). Sortiment dopĺňajú fragmenty hlineného výmazu a dotvárajú tak obraz o rôznosti použitých stavebných techník na južnom predmestí. Žiadna z tehál sa nezachovala v celku, 14 fragmentov poskytlo údaje o šírke a hrúbke, 29 fragmentov o hrúbke. Prehlad všetkých zmeraných rozmerov, umiestnený pri opise nálezov objektov, prezrádza rozmanitú škálu formátov. Doklad o rôznorodosti ponúkajú i d’alšie z pozorovaných charakteristík. Precízne zarovnanie niektorých exemplárov striedajú viditelné pracovné stopy, ktoré odhalujú nedôsledné úpravy povrchu pred vysušením. Viackrát sa $\mathrm{v}$ hmote objavili nezvykle vel'ké kamienky. Až sedem exemplárov (16 \%) malo slinutý, teda výrazne spečený charakter. V niektorých prípadoch vysoký žiar spôsobil až deformáciu. Na jednej z tehál zo studne 2 sa nachádzal pretlačený pásik, pri ktorom nemožno vylúčit, že je pozostatkom značky (tab. III: 3). Nachádza sa v centrálnej časti vrchnej strany tehly a bol pretlačený ešte pred výpalom. Tehla je práve v týchto miestach zlomená. Druhá jej čast’ sa nezachovala, a tak prípadné pokračovanie „značky“" nemožno overit. Nie menej pravdepodobné však môže byt vysvetlenie, že ide o neintencionálny náhodný zásah pracovným nástrojom.

Fragment dlaždice má vyhladený povrch, jemnejšiu keramickú hmotu a rovné hrany. Hrúbka dlaždice je 4,4 cm, získal sa tiež rozmer jednej strany, a to $19,1 \mathrm{~cm}$. Pôvodný tvar dlaždice sa určit nedá. Z vel'kej prevahy jednoduchých štvorcových dlaždíc s rovnými hranami, ktoré sú typické pre región a obdobie včasného novoveku (Čurný 2010, 266), však možno predpokladat práve tento tvar.

Z kovových predmetov je zaujímavý nález štyroch strieborných mincí z dna studne 2, ktoré boli nájdené pri sebe. Ide o pol'ské jedenapolgroše, tzv. polturáky Žigmunda III (tab. II: 1). Dva z nich sú zn. líška z rižskej mincovne (Hunka 1997, 104; tab. 4f: 177), dva z územia Pol'ska (pravdepodobne Bydgoszcz; Hunka 1997, 101; tab. 4d: 141). Mince sú z obdobia rokov 1614-1629, jedna je s istotou z roku 1624. $Z$ dna studne 2 pochádza železné koleso $\mathrm{s}$ priemerom $21,5 \mathrm{~cm}$. Je z tenkého pásového plechu so štyrmi lúčmi, ktoré pozostávali z dvoch prekrížených pásov nakované k okružiu (tab. II: 7). Hrana okružia nemá žliabok a na krížení lúčov sa nenachádza otvor, preto je nepravdepodobné, že by šlo o pozostatok kladkového mechanizmu studne. Absencia otvorov diskvalifikuje možnosṫ okutia dreveného rumpálu. Bližšia interpretácia nálezu je nateraz otvorená. Nález bol vyzdvihnutý v celku a v značne skorodovanom stave. Po ošetrení sa z neho zachovalo približne iba 40 \%. Spolu s kolesom sa našla i sekera (tab. II: 8). Bola bez značky. Ďalšie železné nálezy, klince, podkova a čepel’ noža sú fragmentárne, nevýrazné. Zo začistovania priestoru v blízkosti situácií 22-24 pochádza nález olovnice (tab. V: 1) i malého kovového nitu (tab. V: 2).

\section{ZÁVER}

Archeologický výskum na juhozápadnom nároží Palackého a Jantárovej ulice odhalil už len nepatrné relikty osídlenia južného predmestia z obdobia konca stredoveku a z včasného novoveku. Jeden väčši a štyri malé zemné objekty nemajú vel'kú výpovednú hodnotu o charaktere osídlenia. Koncentrácia troch studní na relatívne malej ploche však dovoluje predpokladat', že počas celého spomenutého obdobia stáli v týchto miestach obydlia s dvorovým zázemím. Početné zastúpenie fragmentov stavebnej keramiky, výmazu, ale i kachlíc v nálezovom fonde je indikátorom dobrého štandardu bývania.

Skúmané objekty poskytli málopočetný a nie vel’mi výrazný súbor nálezov z oboch spomenutých horizontov. Možno konštatovat', že získané artefakty neprekračujú rámec doteraz známeho dobového sortimentu nálezov, skôr doň bezo zvyšku zapadajú. Hodnotu im pridáva fakt, že obohatili velmi úzku škálu doteraz známych nálezov z priestoru bývalých košických predmestí. 


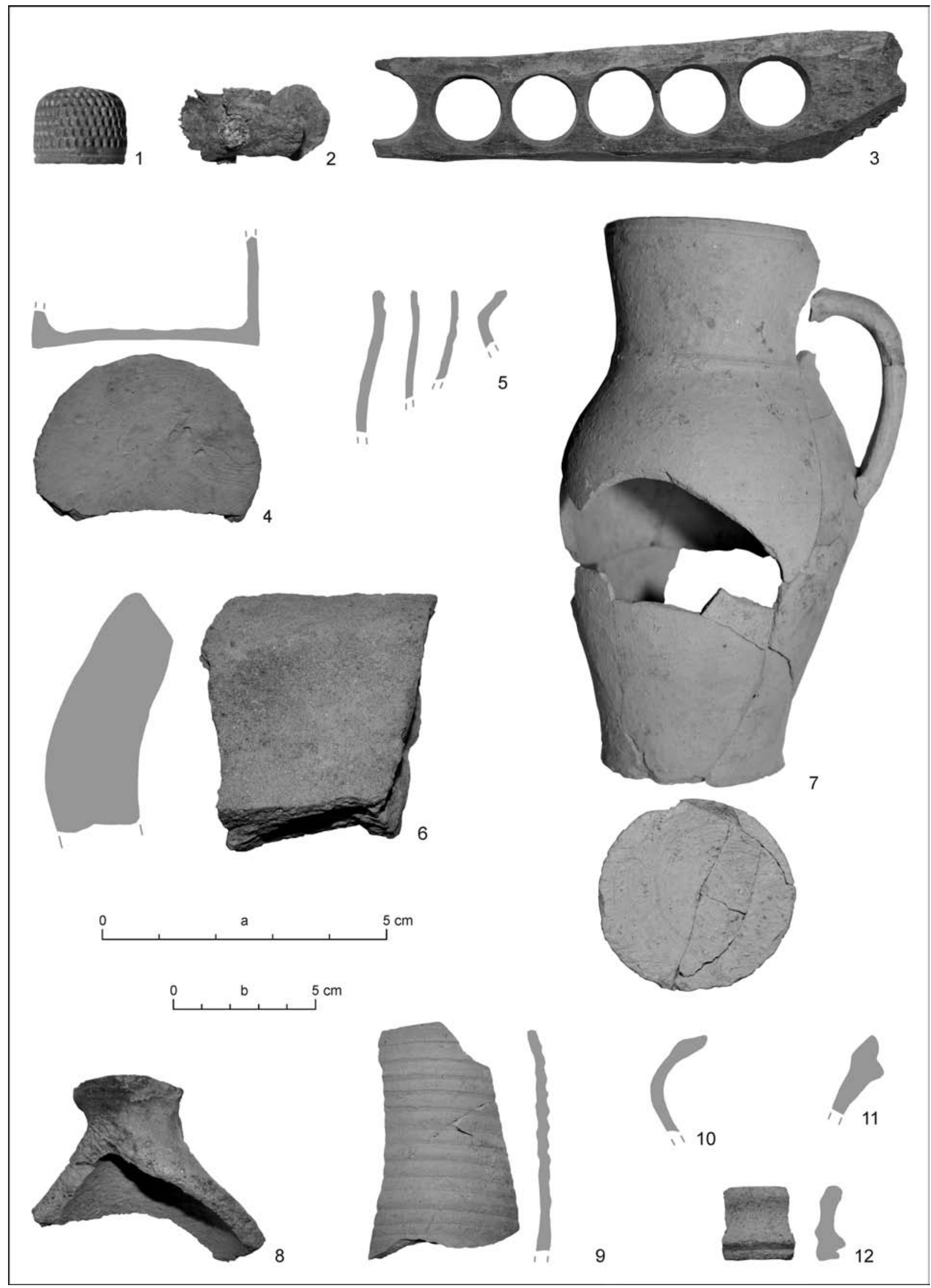

Tab. I. Košice, Duett. JZ nárožie Palackého a Jantárovej ul. 1-7 - situácia 16; 8-11 - situácia 19; 12 - situácia 9. Foto A. Balogh. Mierka: $\mathrm{a}-1-3 ; \mathrm{b}-4-12$. 


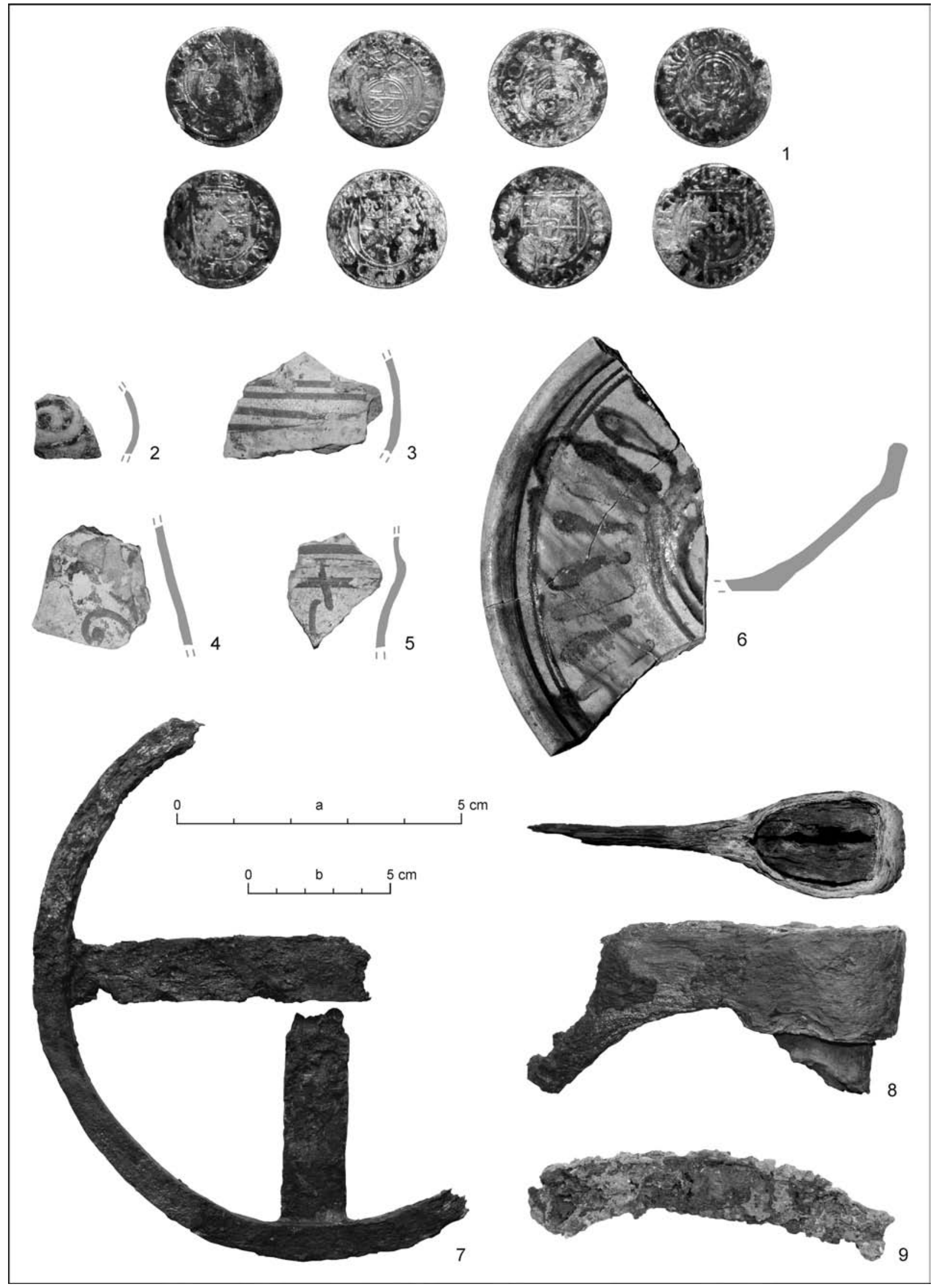

Tab. II. Košice, Duett. JZ nárožie Palackého a Jantárovej ul. 1-9 - situácia 20. Foto A. Balogh. Mierka: a - 1; b-2-9. 

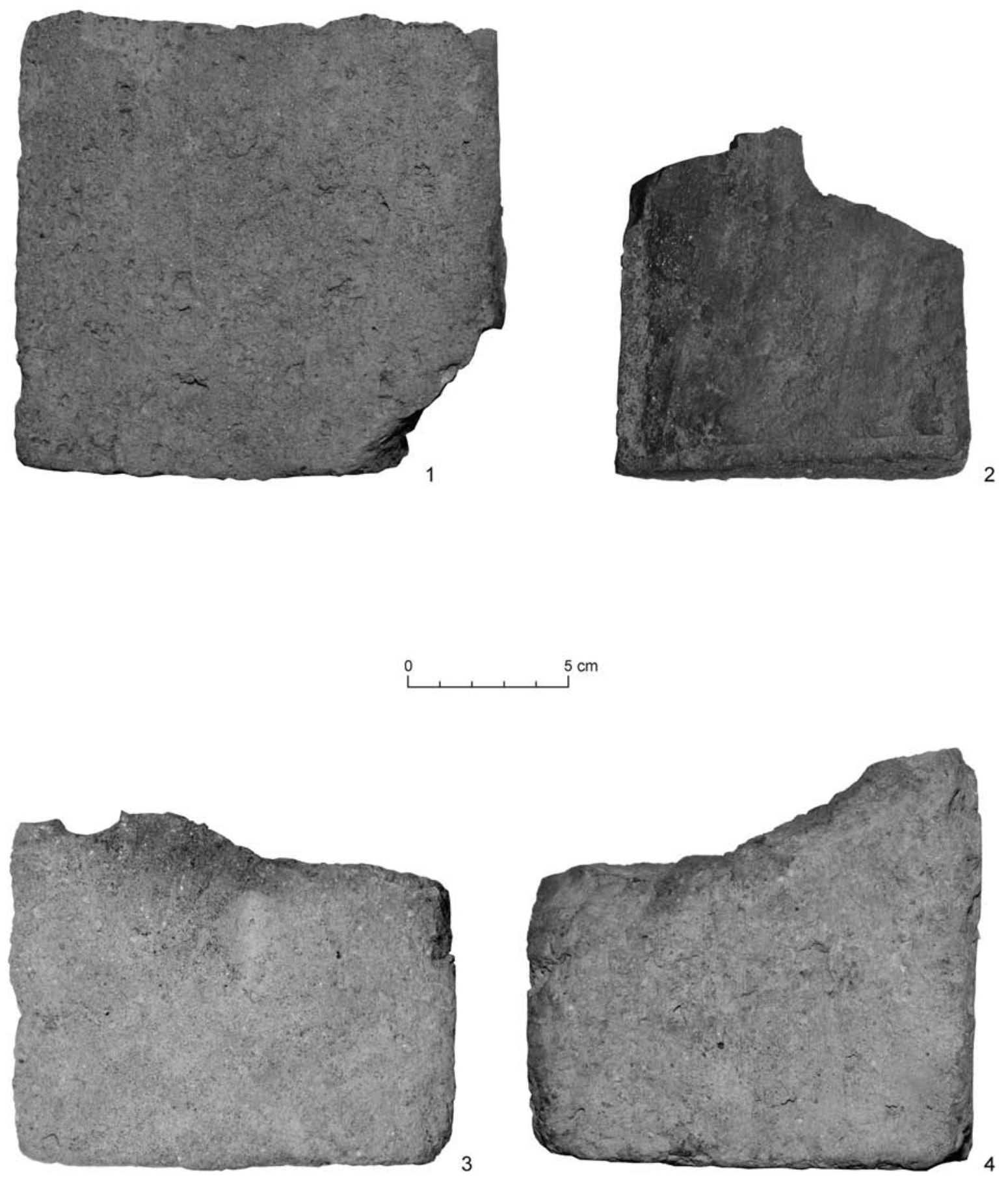

Tab. III. Košice, Duett. JZ nárožie Palackého a Jantárovej ul. 1-4 - situácia 20. Foto A. Balogh. 


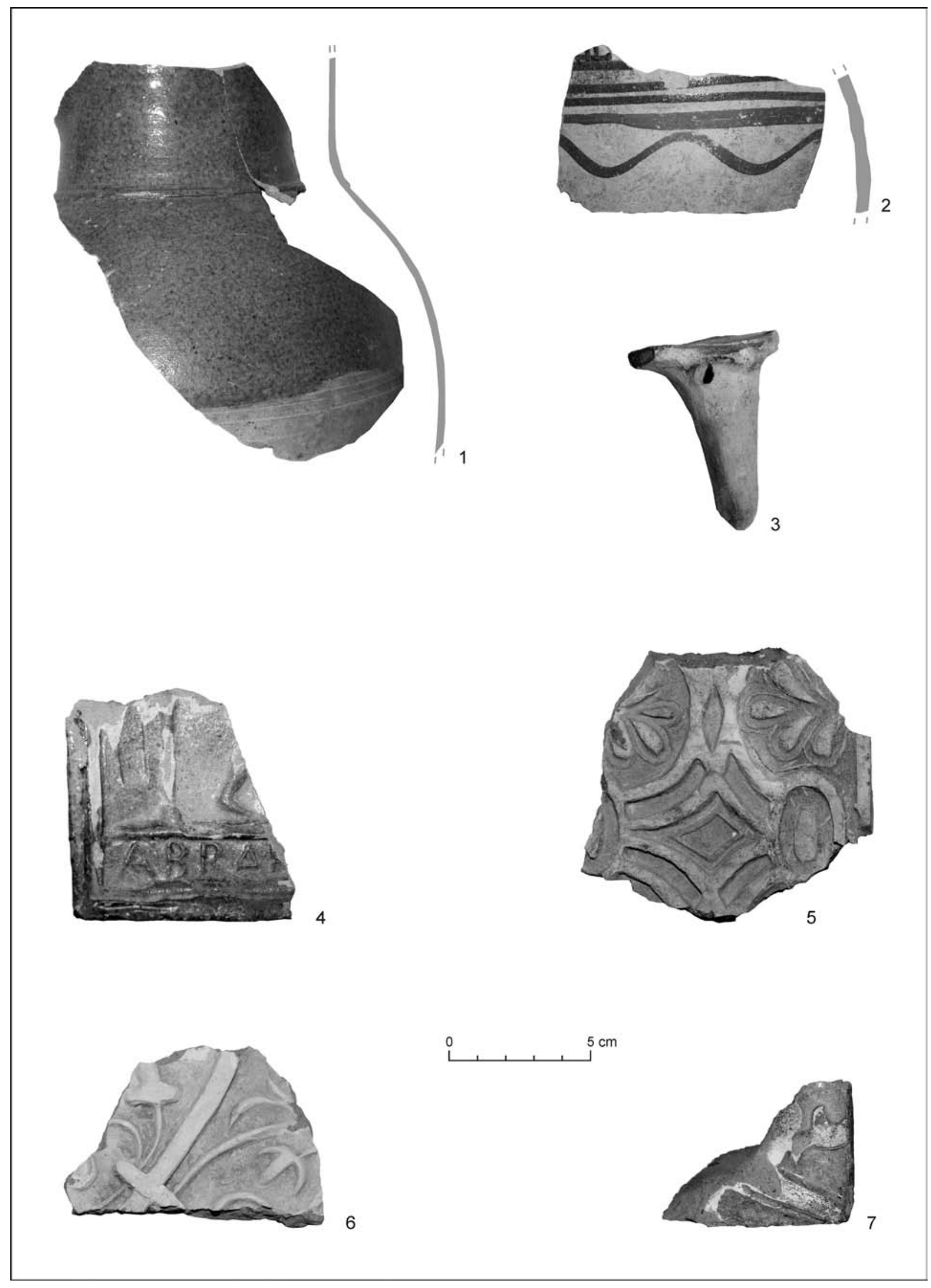

Tab. IV. Košice, Duett. JZ nárožie Palackého a Jantárovej ul. 1-7 - situácia 21. Foto A. Balogh. 


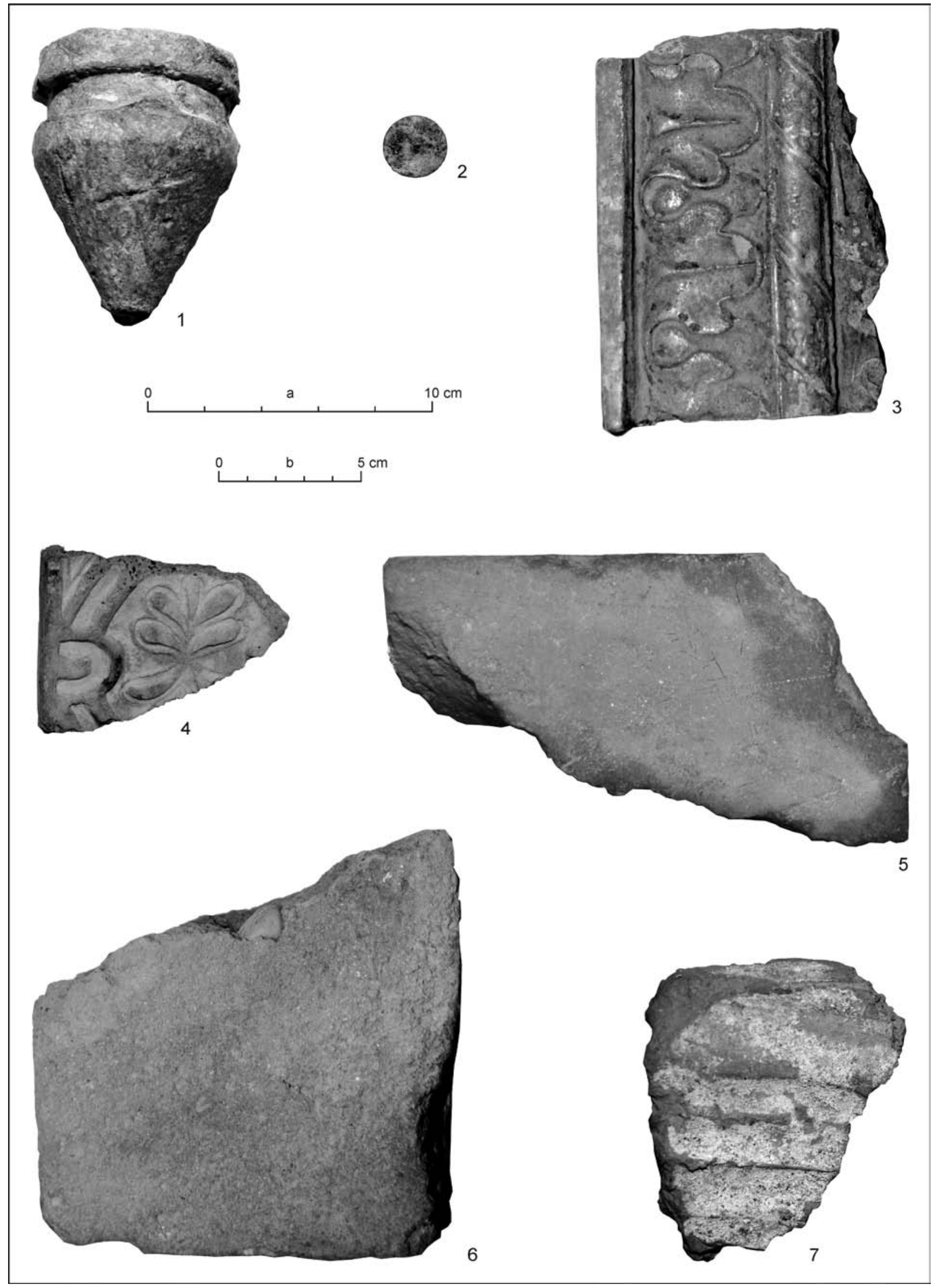

Tab. V. Košice, Duett. JZ nárožie Palackého a Jantárovej ul. 1, 2 - zo začistovania priestoru pri situácii 22 a 23;3-7 - situácia 21. Foto A. Balogh. Mierka: $a-1,2 ; b-3-7$. 


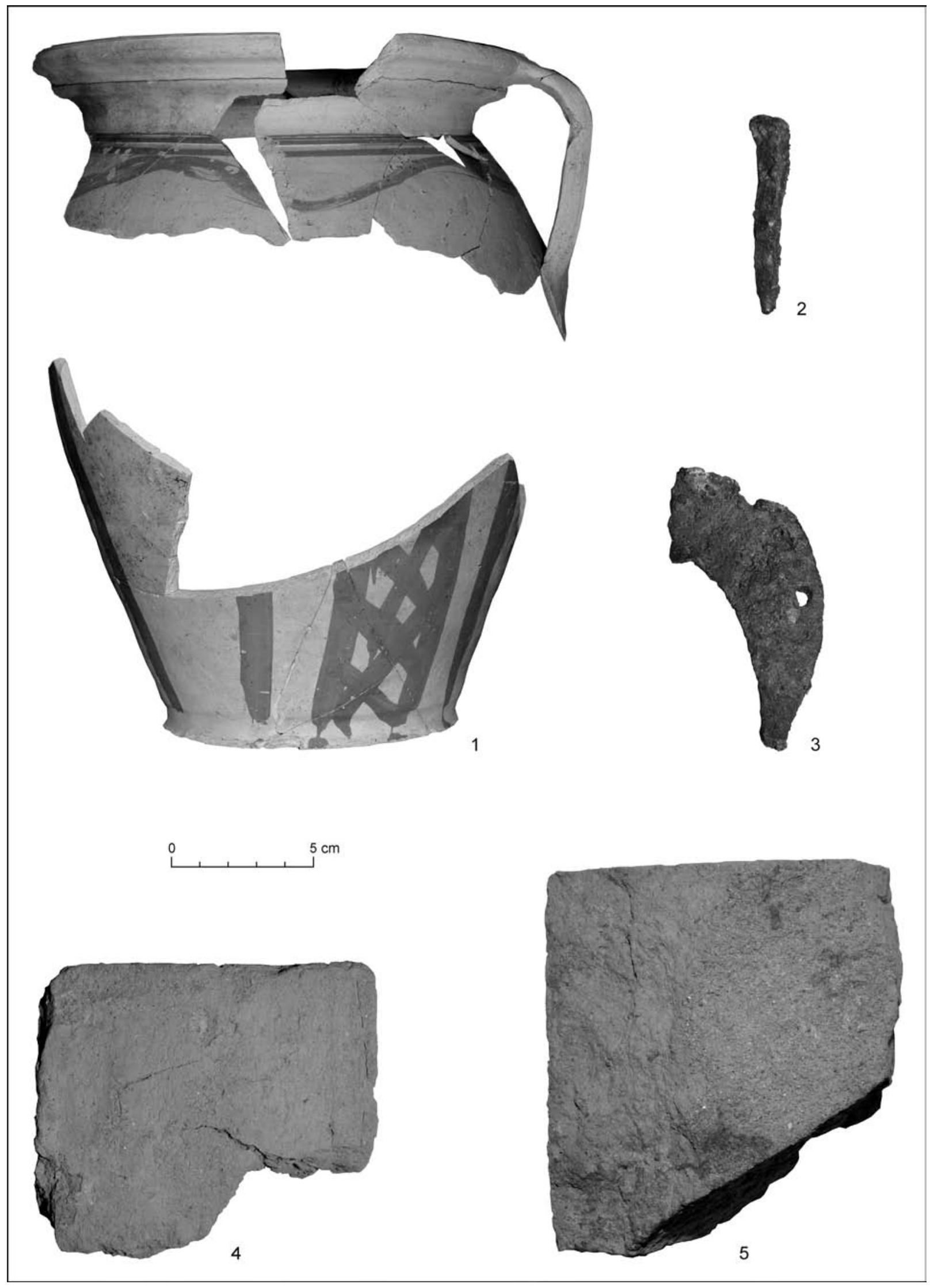

Tab. VI. Košice, Duett. JZ nárožie Palackého a Jantárovej ul. 1-5 - situácia 24. Foto A. Balogh. 


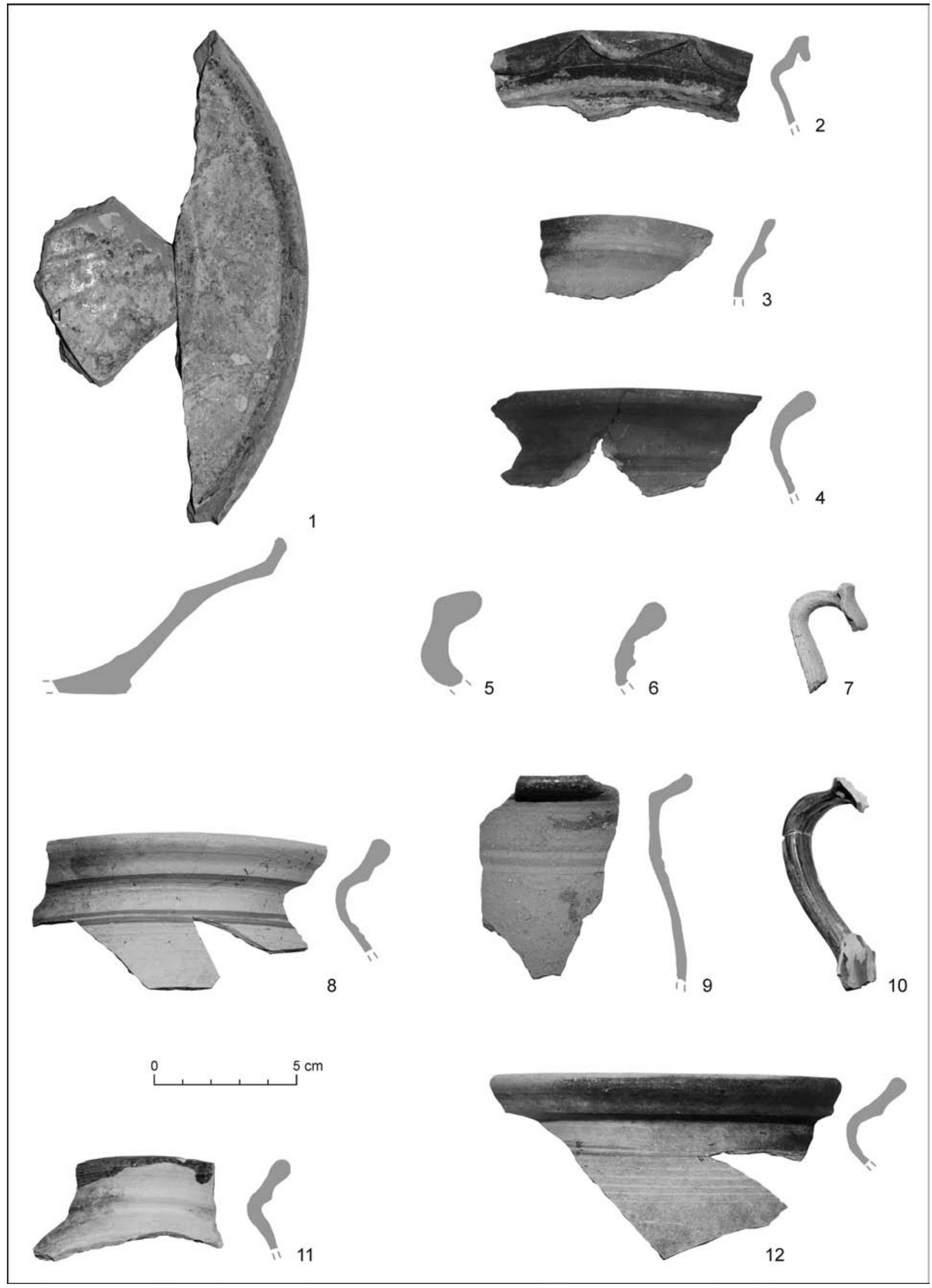

Tab. VII. Košice, Duett. JZ nárožie Palackého a Jantárovej ul. 1-12 - situácia 24. Foto A. Balogh. 


\section{LITERATÚRA}

Archív mesta Košice 1

Archív mesta Košice 2

Bal/Jenö/Kauffmann 1910-1913

Čurný 2010

Čurný 2015

Duchoň 2000-2001

Ďurišová 2013

Gašaj 2014

Gruia 2013

Halaga 1993

Hunka 1997

Chovanec et al. 1996

Kyncl 2018

Lamiová-Schmiedlová 1970

Lamiová-Schmiedlová 1995

Lamiová-Schmiedlová/Miroššayová 1991 Magdoško 2013

Magdoško 2017

Orosová/Žažová 2011

Österreichisches Staatsarchiv Wien 1671

Pástor 1959

Rusnák 2009a

Rusnák $2009 b$

Rusnák 2014

Slivka 1978

Uličný 2014

Uličný 2003

Uličný 2004

Uličný 2008

Varsik 1948

Wick 1936
AMK, MMK, TA. Thesaurus, C - Hospitale 48.

AMK, Tabularium metropol. Civitatis Cassoviensis, II., Schvarzenbachiana, šk. 45, spis 9127/1671.

J. Bal/F. Jenő/A. Kauffmann: Hain Gáspár Lőcsei krónikája. Lőcse 1910-1913.

M. Čurný: Nové nálezy stredovekej a včasnonovovekej stavebnej keramiky z Košíc. Archaeologia Historica 35, 2010, 253-270.

M. Čurný: Tehla a stavebná keramika v architektúre stredovekých a včasnonovovekých Košíc. In: Forum Urbes Medii Aevi 9/1-2. Cihla a stavební keramika v městské architektuře středověku a novověku ve střední Evropě. Brno 2015, 173-185.

J. Duchoň: Počiatky Košíc vo svetle najnovších historických archeologických výskumov. Historica Carpatica 31/32, 2000-2001, 7-19.

M. Ďurišová: Archeologické nálezy v uliciach Košíc - studne. In: Mesto a dejiny 1. Košice 2013, 40-52.

D. Gašaj: Nemeliem nemeliem, zobrala mi voda mlyn. Nález predmetov zo 17. storočia v Mlynskom jarku v Košiciach. Sprievodca k výstave. Košice 2014.

A. M. Gruia: Religious representations on stove tiles from the medieval Kingdom of Hungary. Cluj-Napoca 2013.

O. R. Halaga: Počiatky Košíc a zrod metropoly. Košice 1993.

J. Hunka: Orientačná príručka európskych mincí 16.-20. storočia. II. Mince Pol'ska (1506-1864). Nitra 1997.

J. Chovanec/K. J. Dankó/I. Feld/E. Tamás: A gótikától a habánokig. Od gotiky po habánov. Kályhacsempék Abaúj, Sáros és Zemplén vármegyékből. Kachlice z bývalej Abovskej, Šarišskej a Zemplínskej župy. Kiállitási katalógus. Sárospatak 1996.

T. Kyncl: Dendrochronologické datování dřevěných konstrukčních proků nalezených při archeologickém výzkumu "Košice-Duett“. Výzkumná správa 025a-18. Dokumentácia DendroLab Brno. Brno 2018.

M. Lamiová-Schmiedlová: Súpis výskumov z rokov 1945-1968. In: Východoslovenský pravek 1 . Košice 1970, 139-163.

M. Lamiová-Schmiedlová: Záchranný výskum na novovekom cintoríne v Košiciach. AVANS 1993, 1995, 87, 88.

M. Lamiová-Schmiedlová/E. Miroššayová: Archeologická topografia. Košice 1991.

D. Magdoško: Kostoly a špitály na predmestiach Košíc v stredoveku. Mesto a dejiny 2, 2013, 17-37.

D. Magdoško: K vzniku a správe predmestí stredovekých Košíc. Historický časopis 65, 2017, 591-616.

M. Orosová/H. Žažová: Košická citadela. Košice 2011.

Österreichisches Staatsarchiv Wien, Kriegsarchiv, Akten des Wiener Hofkriegsrates, 1671 September No. 227. Exp. fol. 1671, 15-18.

J. Pástor: Zpráva o archeologickom výskume Východoslovenského múzea v Košiciach v roku 1958. Múzeum 6, 1959, 613-636.

R. Rusnák: Košice v stredoveku. Na podklade archeologických výskumov. Dizertačná práca (AÚ SAV v Nitre). Nitra 2009. Nepublikované.

R. Rusnák: Novšie nálezy stredovekých kovových predmetov z Košíc. Archaeologia historica 34, 2009, 393-407.

R. Rusnák: Vývoj mestskej domovej parcely na príklade Mäsiarskej 57/A v Košiciach. Slovenská archeológia 62, 2014, 315-398.

M. Slivka: Stredoveké hutníctvo a kováčstvo na východnom Slovensku 1. Historica Carpatica 9, 1978, 217-263.

F. Uličný. Začiatok a vývoj meštianstva a mesta Košice do polovice 14. storočia. In: M. Hajduová/M. Bartoš (ed.): Košice v súradniciach európskych dejín. Košice 2014, 44, 45.

M. Uličný: Vel'ká stredoveká kolonizácia a keramická produkcia na východnom Slovensku. Archaeologia Historica 28, 2003, 611-620.

M. Uličný: Premeny východoslovenskej keramiky v 13.-17. storočí. Dizertačná práca (Archeologický ústav SAV Nitra). Prešov 2004. Nepublikované.

M. Uličný: Včasno-novoveká keramika z hradu Šariš. In: Archeologia okresu nowozytnego w Karpatach polskich. Krosno 2008, 511-524.

B. Varsik: Slovenská ulica v Košiciach a vznik mesta Košíc. Historica Slovaca 6/7, 1948, 83-94.

V. Wick: Dóm sv. Alžbety v Košiciach. Košice 1936. 


\title{
New Archaeological Sources Associated with Settlement of Košice Suburbs in the Middle Ages and Early Postmedieval Period
}

\author{
Rastislav Rusnák
}

\author{
Summary
}

\begin{abstract}
The article summarizes results of the archaeological investigation in the wider centre of Košice, which has brought after several decades - new archaeological sources related to settlement of its southern suburb from the Middle Ages and the Early Postemedieval period. The discovered relics are poor in number and expression and the same applies to the finds of material culture from them. The fact that they have enriched the previously very narrow scale of known finds from the territory of former Košice suburbs adds to their value as well as the fact that despite the above mentioned situation, they have provided a good opportunity for their setting in the local historical and spatial context.

The archaeological rescue research on the southwestern corner of Palackého and Jantárová streets managed to detect 8 features which can be associated with the settlement of the southwestern suburb before 1671. Six features are dated by the finds from their fillings, dating of other two is only assumed on the basis of horizontal stratigraphy. Three features can be dated to the Late Middle Ages (contexts 9, 16, 19; Fig. 3, 5, 6) and five features are dated to the Early Postmedieval period (contexts 20-24; Fig. 9, 12, 14-16). The typological scale of the detected features is not very wide. There are four simple earth pit features, one hearth and three wells. The finds of three wells seem to be most interesting in relation to assessment of the settlement's character (contexts 16, 20,21). The wells had circular groundplans and were built of drylaid quarry stones. The outer diameter of the steening varied between 150 and $165 \mathrm{~cm}$, the inner diameter was approx. $85 \mathrm{~cm}$. In all features, a square wooden frame construction was situated under the stone construction. In two of them, it was only preserved in a negative (contexts 16, 21), in one feature (context 20), it was preserved in a relatively good condition and provided samples for dendrochronological analysis. For context 20 - well 2 and context 21 - well 3, year 1671 can be considered the year of their extinction. In that time, the whole southern suburb was demolished to provide space for a citadel. The dendrochronological data obtained from the frame construction of context 20 - well 2 also enables dating of its construction to the period after 1576. Filling of context 16 - well 1 provided only chronologically compact late medieval material. The well, thus, had probably become extinct before the end of the 15 th century. Relation to the above mentioned events from 1491 can be considered as possible as well.
\end{abstract}

With the exception of one restorable vessel (Pl. V: 7), the collection of late medieval pottery sherds is poor. Most of the preserved rims were thin-walled, mainly simply everted rims of tableware, used especially for storing or drinking liquids (Pl. I: 4, 7, 9). Fragment of a hod is notheworthy (Pl. I: 6). Other detected material included multiple small fragments of bricks and fragments of clay daub, a well preserved iron thimble (Pl. I: 1), parts of a knife handle with wooden plates (Pl. I: 2) or bone raw material for production of buttons (Pl. I: 3).

The obtained collection of early postmedieval pottery from the site is not very numerous and we can say it is also not very representative. Only minimum of the vessels are restorable (Pl. VI: 1), there are mostly small sherds. However, they sufficiently document the typological and ornamental diverstity of pottery production brought in by the Early Postmedieval period. Kitchen ware as well as tableware are represented, together with unslipped vessels decorated with red paint (Pl. IV: 2) or polychromy (Pl. II: 3-5), variously glazed pottery or folk faience (Pl. II: 2).

Several types of stove-tiles with tapestry motifs are complemented with a fragment of a stove-tile with a figural scene and an inscription (Pl. IV: 4). The preserved part of the inscription says ABRAH and clearly points to the Old Testament motif of Abraham and Isaac. An identical stove-tile dated to 1562 (Gruia 2013, 323) comes from the nearby castle of Füzér (H) (Chovanec et al. 1996, 29). The remaining fragments of stove-tiles bear various tapestry patterns with stylized geometrical-floral ornament (Pl. IV: 5-7; V: 3, 4).

Finds of building ceramics are also rather frequent. There are mostly fragments of bricks, roof tiles are also represented and there is also one exemplar of a tile (Pl. V: 5).

Among metal artifacts, attention is attracted to the find of four silver coins from the bottom of well 2 which were found close to each other. They are Polish one-and-a-half groschen, so-called poltoraks of Sigismund III (Pl. II: 1). An iron wheel with diameter of $21.5 \mathrm{~cm}$ also comes from the bottom of well 2. It is made of a thin band-shaped plate with four spokes consisting of two crossed bands attached to the rim (Pl. II: 7). Together with the wheel, an axe was discovered (Pl. II: 8). It did not bear any mark. Other iron finds - nails, a horseshoe, a knife blade - are fragmentary and indistinct. Finds of a plumb (Pl. V: 1) and a small metal rivet (Pl. V: 2) come from the trimming of the area near features in contexts $22-24$.

Fig. 1. Segment of the map of Košice from 1742 (OrosoválŽažová 2011, 60) with indicated previous and current archaeological document of suburban settlement. a - approximate location of the discovery of a pottery kiln from 1959 in Srobárova 57; b - approximate location of the discovery of a medieval settlement feature from 1963, near the edge 
of the postmedieval town cemetery; c - location of a smaller cemetery, partly detected by the investigation in 1993; $\mathrm{d}$-approximate location of suburban finds refered to in the article.

Fig. 2. Košice. Location of features within the building plot on the southwestern corner of Palackého and Jantárová streets.

Fig. 3. Košice, Duett. SW corner of Palackého and Jantárová streets. Context 9 (groundplan, W-E cross-section). Drawing by R. Rusnák.

Fig. 4. Košice, Duett. SW corner of Palackého and Jantárová streets. Context 16 - well 1. Photo by R. Rusnák.

Fig. 5. Košice, Duett. SW corner of Palackého and Jantárová streets. Context 16 (groundplan, S-N cross-section). Drawing by R. Rusnák.

Fig. 6. Košice, Duett. SW corner of Palackého and Jantárová streets. Context 19 (groundplan, W-E cross-section). Drawing by R. Rusnák.

Fig. 7. Košice, Duett. SW corner of Palackého and Jantárová streets. Stone cave-in above context 20 - well 2 . Photo by R. Rusnák.

Fig. 8. Košice, Duett. SW corner of Palackého and Jantárová streets. Context 20 - well 2. Photo by R. Rusnák.

Fig. 9. Košice, Duett. SW corner of Palackého and Jantárová streets. Context 20 (groundplan, W-E cross-section; groundplan of frame construction). Drawing by R. Rusnák.

Fig. 10. Košice, Duett. SW corner of Palackého and Jantárová streets. Frame construction of context 20 - well 2 after removal of the stone steening of the well. Photo by R. Rusnák.

Fig. 11. Košice, Duett. SW corner of Palackého and Jantárová streets. Context 21 - well 3. Photo by A. Balogh.

Fig. 12. Košice, Duett. SW corner of Palackého and Jantárová streets. Context 21 (groundplan, W-E cross-section). Drawing by R. Rusnák.

Fig. 13. Košice, Duett. SW corner of Palackého and Jantárová streets. Negative of the frame construction with traces of decayed wood under the stone construction of context 21 - well 3. Photo by A. Balogh.

Fig. 14. Košice, Duett. SW corner of Palackého and Jantárová streets. Context 22 (groundplan, SW-NE cross-section). Drawing by R. Rusnák.

Fig. 15. Košice, Duett. SW corner of Palackého and Jantárová streets. Context 23 (groundplan, SW-NE cross-section). Drawing by R. Rusnák.

Fig. 16. Košice, Duett. SW corner of Palackého and Jantárová streets. Context 24 (groundplan, SW-NE cross-section). Drawing by R. Rusnák.

Pl. I. Košice, Duett. SW corner of Palackého and Jantárová streets. 1-7 - context 16; 8-11 - context 19; 12 - context 9. Photo by A. Balogh. Scale: $\mathrm{a}-1-3 ; \mathrm{b}-4-12$.

Pl. II. Košice, Duett. SW corner of Palackého and Jantárová streets. 1-9 - context 20. Photo by A. Balogh. Scale: a - 1; b-2-9.

Pl. III. Košice, Duett. SW corner of Palackého and Jantárová streets. 1-4 - context 20. Photo by A. Balogh.

Pl. IV. Košice, Duett. SW corner of Palackého and Jantárová streets. 1-7 - context 21. Photo by A. Balogh.

Pl. V. Košice, Duett. SW corner of Palackého and Jantárová streets. 1, 2 - from trimming of the area near contexts 22 and 23; 3-7 - context 21. Photo by A. Balogh. Scale: a - 1, 2; b-3-7.

Pl. VI. Košice, Duett. SW corner of Palackého and Jantárová streets. 1-5 - context 24. Photo by A. Balogh.

Pl. VII. Košice, Duett. SW corner of Palackého and Jantárová streets. 1-12 - context 24. Photo by A. Balogh.

Mgr. Rastislav Rusnák, PhD.

Fakulta umení Technickej univerzity v Košiciach

Katedra teórie a dejín umenia

Watsonova 4

SK - 04200 Košice

rastislav.rusnak@hotmail.sk 
